\title{
SMALL STRUCTURAL DIFFERENCES BETWEEN TWO FERROCENYL DIPHENOLS DETERMINE LARGE DISCREPANCIES OF REACTIVITY AND BIOLOGICAL EFFECTS
}

Federica Tonolo, ${ }^{a}$ Michèle Salmain, ${ }^{b}$ Valeria Scalcon, ${ }^{a}$ Siden Top, ${ }^{b}$ Pascal Pigeon, ${ }^{b, c}$ Alessandra Folda, ${ }^{a}$ Benoit Caron, ${ }^{d}$ Michael J. McGlinchey, ${ }^{e}$ Alberto Bindoli, ${ }^{\dagger}$ Gérard Jaouen, ${ }^{\mathrm{b}, \mathrm{c}}$ Anne Vessières, ${ }^{\text {b }}$ Maria-Pia Rigobello ${ }^{\text {a }}$

a) Dipartimento di Scienze Biomediche, Università di Padova, Via Ugo Bassi 58/b, 35131 Padova, Italy.

b) Sorbonne Université, CNRS, IPCM, 4 Place Jussieu, 75005 Paris, France.

c) Chimie ParisTech, PSL University, 11 rue Pierre et Marie Curie, 75005 Paris, France

d) Sorbonne Université, ISTeP, ALIPP6, 4 Place Jussieu, 75005 Paris, France

e) School of Chemistry, University College Dublin, Belfield, Dublin 4, Ireland

f) Istituto di Neuroscienze (CNR) Sezione di Padova, c/o Dipartimento di Scienze

Biomediche, Via Ugo Bassi 58/b, 35131 Padova, Italy.

* To whom correspondence should be sent

A. Vessières: anne.vessieres@sorbonne-universite.fr

M.P. Rigobello: mariapia.rigobello@unipd.it

Abstract: The ferrocenyl diphenol complexes 1,1-bis(4'-hydroxyphenyl)-2-ferrocenyl-but-1-ene

and

1,2-bis(4'-hydroxyphenyl)-1-ferrocenyl-but-1-ene [(Z)-2], which differ by the relative position of the two phenolic substituents, display dramatically different antiproliferative activities on cancer cells ( $\mathbf{1}$ is far more cytotoxic than $\mathbf{2}$ ). In this study, our goal was to discover the origin of this difference by comparing their reactivity and biological behaviour. In terms of common behaviour, we found that $\mathbf{1}$ and $\mathbf{2}$ are both efficient inhibitors of thioredoxin reductase (TrxR) in vitro after oxidation by a horseradish peroxidase $/ \mathrm{H}_{2} \mathrm{O}_{2}$ system. However, as 1 is only a moderate inhibitor of TrxR in MDA-MB-231 cells, TrxR is probably not the major target responsible for the cytotoxicity of $\mathbf{1}$. In terms of differences, we noted that $\mathbf{1}$ induced a significant redox imbalance characterised by lipid peroxidation and thiol oxidation, and a 
moderate decrease of the mitochondrial membrane potential in breast cancer cells, whereas 2 has almost no effect. These results underline the importance of the trans configuration in the ferrocenyl-double bond-phenol motif, which is present in $\mathbf{1}$ but is cis in (Z)-2.

\section{Introduction}

Metallodrugs based on the coordination chemistry of platinum, such as cisplatin, carboplatin and oxaliplatin, are used alone or in combination in over $50 \%$ of cancer treatments. ${ }^{1-3}$ It is nevertheless well recognised that despite their proven capabilities, these drugs have serious issues, including a general toxicity linked to their lack of selectivity between healthy and damaged cells, a fairly narrow therapeutic range and a tendency to give rise to resistance. ${ }^{1}$ This has led to research into other metallodrugs bearing different metals as well as different types of bonding such as those described by organometallic chemistry and characterised by covalent metalcarbon (M-C) bonds. ${ }^{2,4,5}$ The development of bioorganometallic chemistry with its novel functionalities has provided access to innovative properties that make it possible to address different biological targets. ${ }^{4-7}$ In this context, we have developed species incorporating ferrocene onto the tamoxifen skeleton, thus providing a new angle from which to evaluate what can be achieved with antitumour agents (protein targets, selectivity for cancerous cells, avoidance of resistance effects, multiple mechanisms). ${ }^{8-12}$ This family of complexes, known as ferrocifens, share a "ferrocenyl-alkene-phenol" redox motif, which generates organometallic quinone methides (QMs) as primary metabolites, the electrophilicity of which can be modulated by changing their substituents. ${ }^{8,}{ }^{13-16}$ Ferrocifens are proving, both chemically and biologically, to be a very rich resource. ${ }^{9-12,17}$

In the ferrocifen family, the diphenolic complex 1 (Figure 1) was one of the first to be synthesised and studied. It was initially designed for investigating the influence of the dimethylaminopropyl substituent in $\mathbf{3}$ on its cytotoxic activity toward the hormone-independent breast cancer cell line MDA-MB-231. ${ }^{18,19}$ Fortuitously, the cytotoxic activities of 1 and 3 were similar $\left(\mathrm{IC}_{50}=0.6\right.$ and $0.5 \mu \mathrm{M}$, respectively, on MDA-MB-231 cells), which makes them hits among this family of compounds, which also includes the ansa-ferrociphenol complex 5. ${ }^{10,20}$ Complex $\mathbf{1}$, formulated in lipid nanocapsules, was also the first in the family to show an antitumour effect in vivo on 
rats with ectopic or orthotopic implanted tumours from glioblastoma (rat $9 \mathrm{~L}$ cells). ${ }^{10}$, 11, 21 However, limited cell biology studies on 1 were performed on glioma and melanoma cell lines. ${ }^{22,23}$
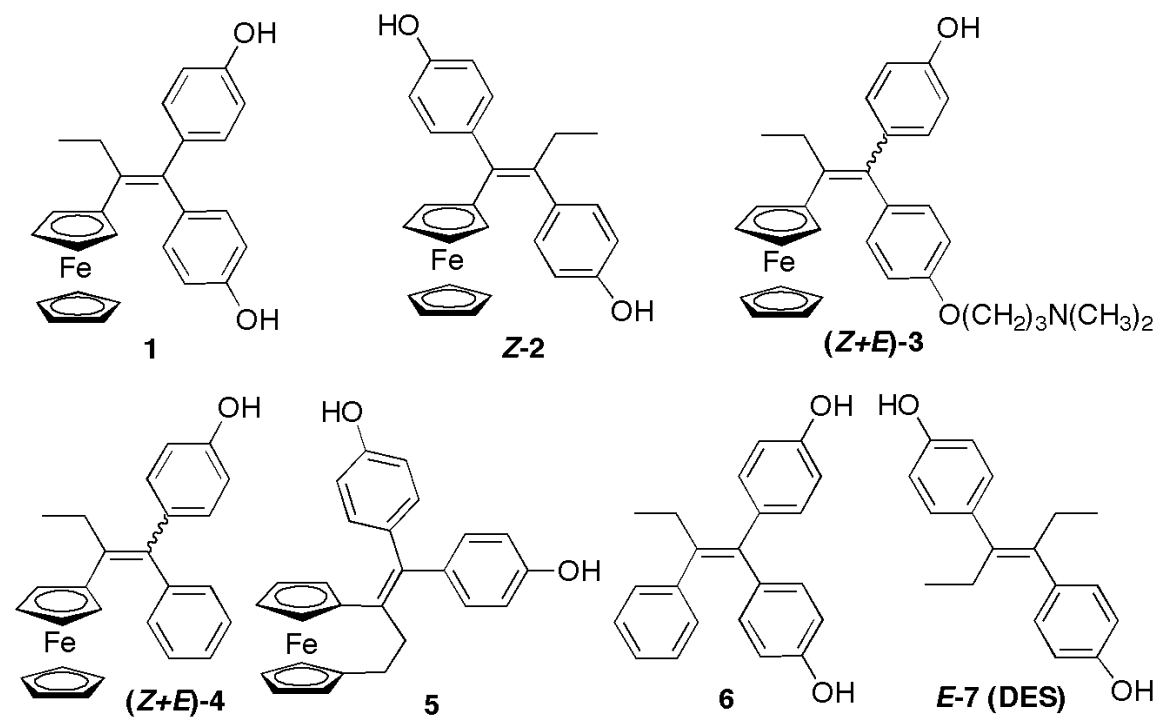

Figure 1. Structures of ferrocenyl complexes discussed in this paper and their corresponding organic molecules.

Subsequently, the ferrocenyl diphenol $\mathbf{2}$, a regioisomer of $\mathbf{1}$ differing in the position of the two phenolic substituents on the central carbon-carbon double bond, was synthesised but its cytotoxicity was unexpectedly much lower than that of $\mathbf{1} .^{24,25}$ Recent results on 4, the monophenol ferrocenyl complex, suggested that the mechanism of action of phenolic ferrocifens might differ from that of the tamoxifen-like complex $3 .^{26}$ This difference was associated with the presence on $\mathbf{3}$ of the dimethylaminopropyl side chain. Recently, the QM of $\mathbf{3}$ was found to have strong inhibitory activity on the enzyme thioredoxin reductase (TrxR) ${ }^{26} \operatorname{TrxR}$ belongs to the thioredoxin system, which, together with the glutathione system, is responsible for thiol redox balance. TrxR displays a selenocysteine residue at its $\mathrm{C}$-terminal active site, which acts as a major target of electrophiles as well as many metal complexes. ${ }^{26-30}$ TrxR is often overexpressed in many cancer cell lines and its inhibition brings about cell death. ${ }^{26,28-30}$ Here, we report the results of a set of experiments on $\mathbf{1}$ and $\mathbf{2}$ carried out in an attempt to rationalise their difference in cytotoxicity and also to give clues concerning their possible mechanism of action. For 
this purpose, two breast cancer cell lines-one hormone dependent (MCF-7), the other triple-negative, hormone independent (MDA-MB-231)—were used.

\section{Results}

The syntheses of $\mathbf{1}$ and $\mathbf{2}$ were accomplished using the McMurry cross-coupling reaction of ketones according to a published procedure. ${ }^{19,24,25}$ Interestingly, complex 2 is obtained mainly as the $Z$ isomer ( $Z / E, 93: 7)$ whereby the two phenol groups are trans disposed. In addition, it was found that (Z)-2 does not isomerise significantly even after one week in DMSO $(Z / E, 99: 1) .{ }^{24}$ Complex 2 is the organometallic analogue of $(E)-7$ (diethylstilbestrol, DES), and also undergoes slow isomerisation. ${ }^{31}$ The almost exclusive formation of (Z)-2, and its resistance to isomerisation, is attributed to the steric problems that arise by positioning the two phenol moieties face to face in (E)-2. Preferential formation of (Z)-2 in the McMurry reaction is determined by the transition state for radical coupling in which steric factors are minimised. ${ }^{32}$

\section{Enzymatic oxidation studies of 1,2 and the organic molecules 6 and 7 with the horseradish peroxidase (HRP) $/ \mathrm{H}_{2} \mathrm{O}_{2}$ system}

Enzymatic oxidation reactions were performed with a fourfold molar excess of $\mathrm{H}_{2} \mathrm{O}_{2}$ in the presence of HRP at pH 8.1 or 5.0 and were monitored by UV/Vis spectroscopy.

\section{Enzymatic oxidation of 1 and 6}

For 1, a bright pink adduct $\left(\lambda_{\max }=565 \mathrm{~nm}\right)$ was formed rapidly at $\mathrm{pH} 8.1$ (Figure 2, upper panel), whereas the same experiment performed at $\mathrm{pH} 5$ afforded a yellow adduct ( $\lambda_{\max }=416 \mathrm{~nm}$; Figure $S 1$ in the Supporting Information, upper panel). If the experiment was performed at $\mathrm{pH} \mathrm{6.8,} \mathrm{we} \mathrm{observed} \mathrm{the} \mathrm{presence} \mathrm{of} \mathrm{the} \mathrm{two} \mathrm{bands}$ (Figure S1, lower panel). This behaviour is reminiscent of that previously observed for the ansa-ferrociphenol derivative $5,^{33}$ which lets us conclude that enzymatic oxidation of $\mathbf{1}$ affords the corresponding $\mathrm{QM}$ in the anionic phenolate form $\mathbf{8} \mathbf{A}$ at $\mathrm{pH}$ 
8.1, the neutral phenolic form $8 \mathbf{B}$ at pH 5.0 (Scheme 1), or as a mixture of $8 \mathbf{A}$ and $8 \mathbf{B}$ at the intermediate $\mathrm{pH} 6.8$.
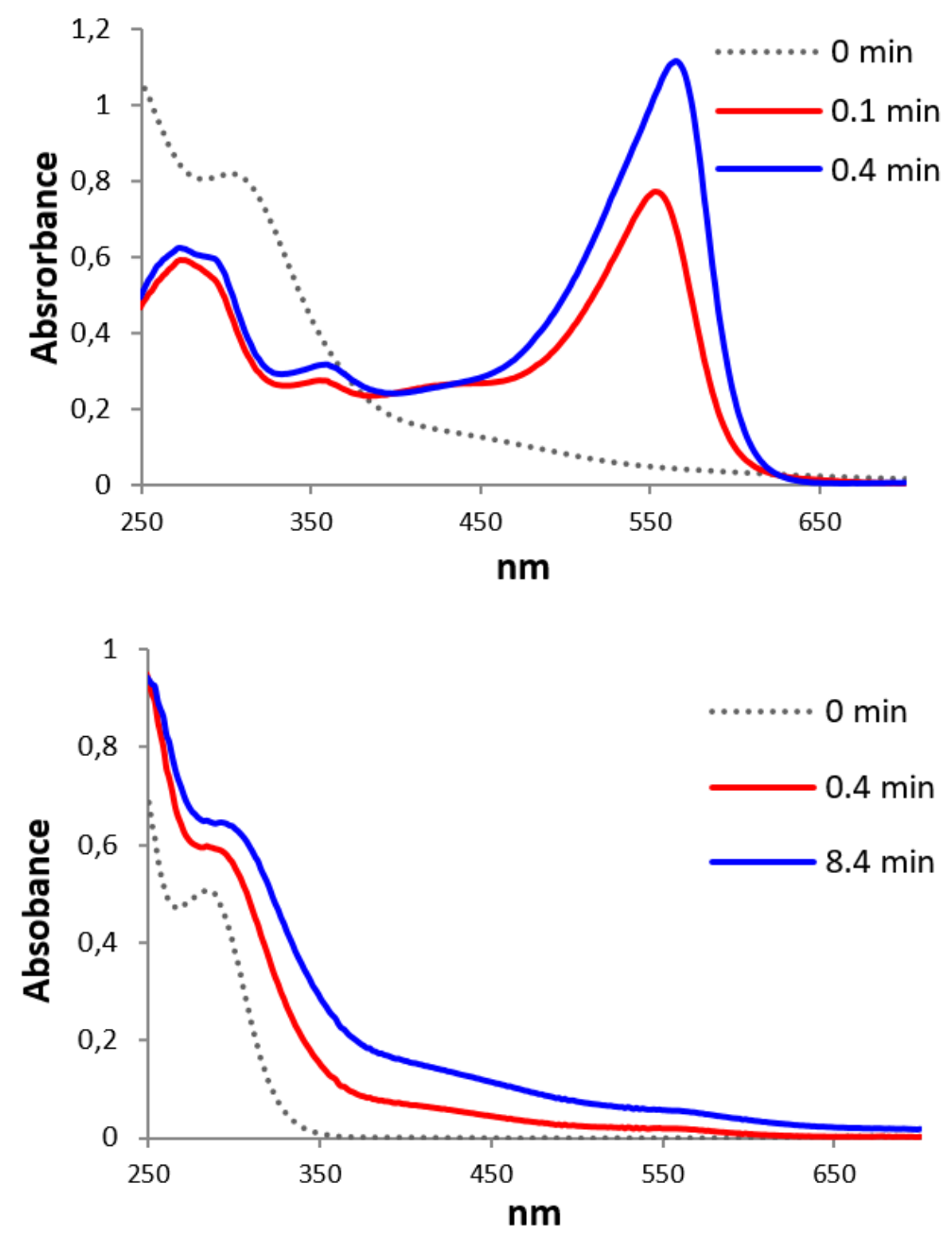

Figure 2. Time evolution of the UV/Vis spectrum of $50 \mu \mathrm{M} 1$ (upper panel) and $\mathbf{6}$ (lower panel) at $25^{\circ} \mathrm{C}$ in the presence of $\mathrm{HRP}(46 \mathrm{nM})$ and $\mathrm{H}_{2} \mathrm{O}_{2}(200 \mu \mathrm{M})$ at $\mathrm{pH} 8.1(0.2 \mathrm{~m}$ Tris. $\mathrm{HCl}, 1 \mathrm{mM}$ EDTA, $10 \%$ DMSO). Upper panel: pure $1(0 \mathrm{~min})$, band centred at $304 \mathrm{~nm}$; after $0.1 \mathrm{~min}$ : bands at 553 (very intense), 358 (weak) and $279 \mathrm{~nm}$ (broad, medium); after $0.4 \mathrm{~min}$ : bands at 565 (intense), 358 (weak) and $279 \mathrm{~nm}$ (broad, medium). Lower panel: pure 6 ( $0 \mathrm{~min}$ ) band centred at $284 \mathrm{~nm}$; after 0.4 and 8.4 min: shoulder at $296 \mathrm{~nm}$. 

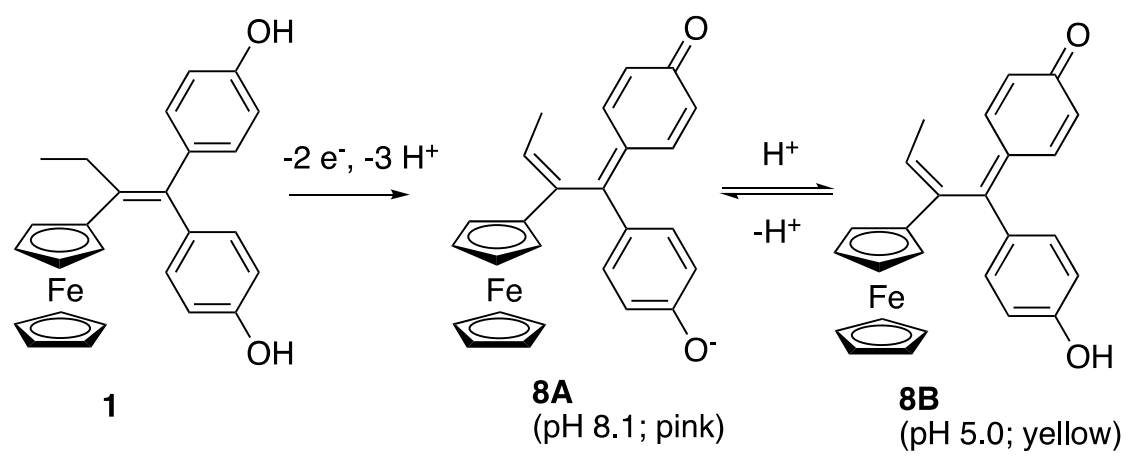

Scheme 1. Proposed sequence of the enzymatic oxidation of 1 by an $\mathrm{HRP} / \mathrm{H}_{2} \mathrm{O}_{2}$ mixture.

The rate of formation of the QM of 1 at $\mathrm{pH} 8.1$ was much faster than that of 5 [rate constant $\mathrm{k}=2.5 \mathrm{~min}^{-1}$ for $\mathbf{1}$ (Figure S2) vs. $0.12 \mathrm{~min}^{-1}$ for $\mathbf{5}$ at $\left.\mathrm{pH} 8\right]^{33}$ its half-life is 12 min, and no intermediate was observed by UV/Vis spectroscopy. These differences can be explained in terms of the ring strain inherent in the ansa structure of $\mathbf{5}$. Complex $8 \mathrm{~B}$ had been prepared previously by chemical oxidation with $\mathrm{Ag}_{2} \mathrm{O}$ and characterised by NMR spectroscopy, ${ }^{34}$ but could not be obtained in the solid state due to its lower stability compared to that of the QM of 4 , which could be isolated. ${ }^{26}$

Complex $\mathbf{1}$ is the organometallic analogue of $\mathbf{6}$, and interestingly, its treatment, in the same conditions, afforded non-identified compounds at both pH 8.1 (Figure 2, lower panel) and $\mathrm{pH} 5.0$ (Figure S3), but certainly not the QM. This indicates that the presence of the redox-active ferrocenyl unit on complex 1 was essential to drive QM formation under oxidative conditions.

\section{Enzymatic oxidation of 2 and 7}

Enzymatic oxidation of 2 at $\mathrm{pH} 8.1$ led to the immediate formation of a blue-green adduct $\left(\lambda_{\max }=302,408\right.$ and $675 \mathrm{~nm}$ ) followed by its conversion into another greenish product ( $\lambda_{\max }=393$ and $629 \mathrm{~nm}$; Figure 3, upper panel). 

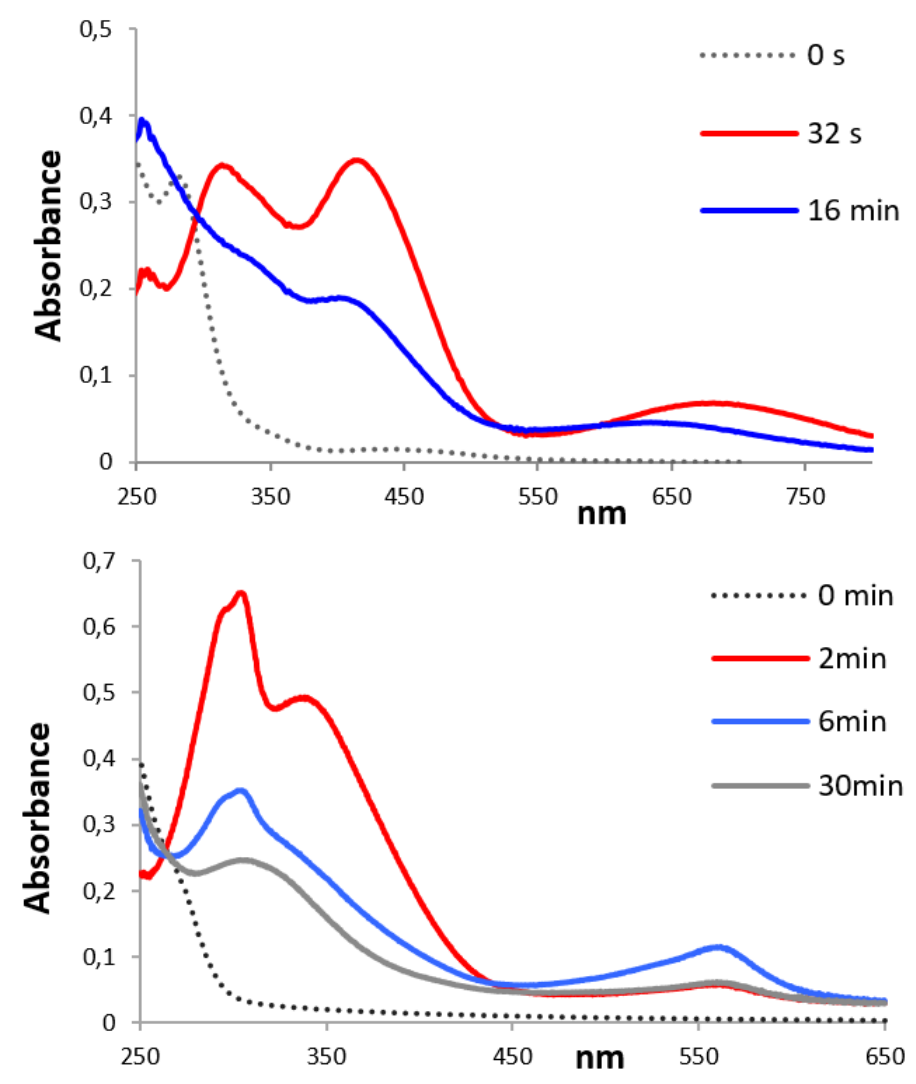

Figure 3. Time evolution of the UV/Vis spectrum of $50 \mu \mathrm{M} 2$ (upper panel) and 7 (lower panel) at $25^{\circ} \mathrm{C}$ in the presence of HRP $(46 \mathrm{nM})$ and $\mathrm{H}_{2} \mathrm{O}_{2}(200 \mu \mathrm{M})$ at $\mathrm{pH} 8.1(0.2 \mathrm{~m}$ Tris. $\mathrm{HCl}, 1 \mathrm{mM}$ EDTA, $10 \%$ DMSO). Upper panel: pure 2 ( $0 \mathrm{~min})$ : band centred at $284 \mathrm{~nm}$; after $32 \mathrm{~s}$ : bands at 683 (broad and weak), 416 and $316 \mathrm{~nm}$ (intense); after $16 \mathrm{~min}$ : bands at 638 (broad and weak) and $408 \mathrm{~nm}$ (intense). Lower panel: pure 7 ( $0 \mathrm{~min}$ ) no characteristic bands; after $2 \mathrm{~min}$ : bands centred at 304 and $338 \mathrm{~nm}$ (intense); after $6 \mathrm{~min}$ : bands at 306 (intense) and $561 \mathrm{~nm}$ (broad and weak), after $30 \mathrm{~min}$ these two bands dramatically decreased in intensity.

The colour of the first species is reminiscent of that of a ferrocenium species, which, according to the previously established mechanism of oxidation of ferrocifens, is the first intermediate to be formed in the sequence of reactions leading to a QM (Scheme S1). ${ }^{17}$ However, an electron paramagnetic resonance (EPR) experiment using a mixture of 2 and $\mathrm{H}_{2} \mathrm{O}_{2} / \mathrm{HRP}$ after a short incubation time invalidated this hypothesis, because no signal corresponding to an iron-centred radical was detected. Indeed, chemical oxidation of 2 by $\mathrm{Ag}_{2} \mathrm{O}$ was previously found to afford the phenol quinone compound 10 resulting from the loss of two electrons and two protons (Scheme 2). ${ }^{24}$ This species was characterised by various spectroscopic techniques; the UV/Vis spectrum showed two characteristic bands centred at 392 and $590 \mathrm{~nm}$ in acetonitrile. 

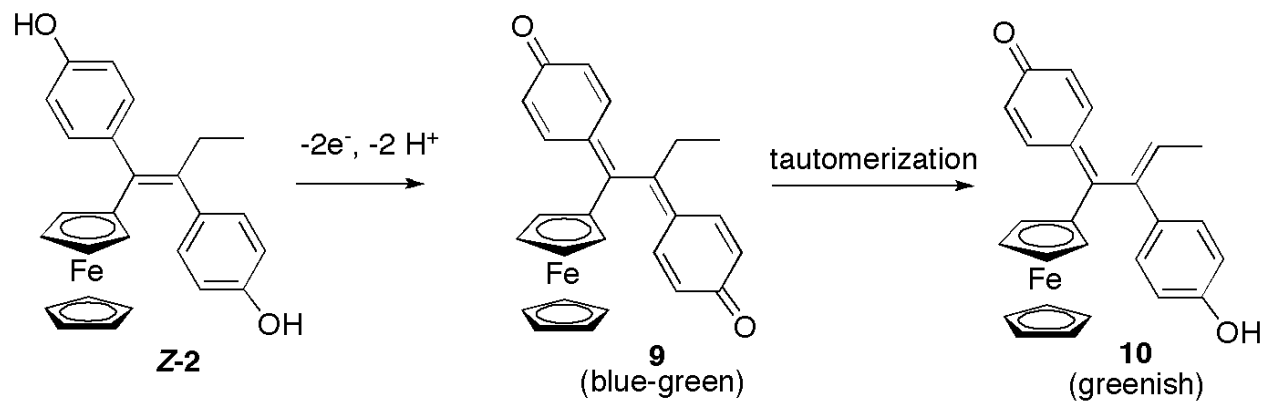

Scheme 2. Sequence of the oxidation of 2 involving loss of 2 electrons and 2 protons leading to 9 , the diquinone methide, then by tautomerisation to the phenol-QM $10{ }^{24}$

The mechanism of the oxidation of $\mathbf{2}$ to $\mathbf{1 0}$ is a two-step process in which the diphenol compound is first rapidly converted into the diquinone $\mathbf{9}$, which undergoes subsequent tautomerisation to afford $\mathbf{1 0}$, the phenol-quinone.

For comparison, the well-known estrogenic molecule 7 was enzymatically oxidised in the same way, and the UV/Vis spectrum of the mixture was recorded over a period of $30 \mathrm{~min}$ (Figure 3, lower panel). Bands centred at 304 and $338 \mathrm{~nm}$ appeared within 2 $\mathrm{min}$, and were readily assigned to the diquinone derivative 11 (Scheme 3). The system gradually evolved toward another species absorbing at 306 and $560 \mathrm{~nm}$. It has been reported that 11 undergoes successive tautomerisations from 12 to 13 by migration of protons from the two ethyl substituents to afford the diphenol (Scheme 3). ${ }^{35}$ The rate of conversion between 12 and $\mathbf{1 3}$ increased with the $\mathrm{pH} .{ }^{35}$ Compound 12, the product of monotautomerisation of $\mathbf{1 1}$, the phenol-quinone analogous to $\mathbf{1 0}$, the final oxidation product of complex 2, has never been isolated. This second tautomerisation is possible for $\mathbf{1 2}$ but not for $\mathbf{1 0}$.

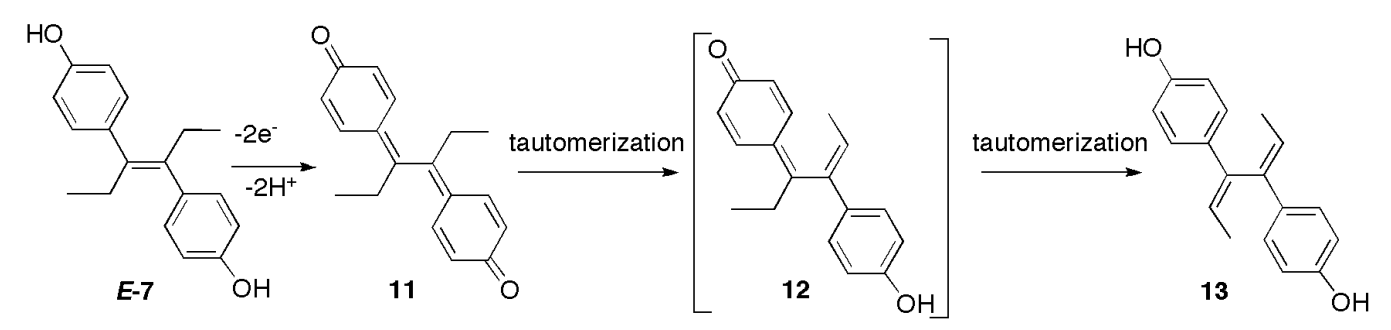

Scheme 3. Sequence of the oxidation of $(E)-7$ involving loss of 2 electrons and 2 protons leading to 11, the diquinone methide, then by a double tautomerisation to the diphenol $13 .{ }^{35}$ 


\section{Study of inhibition of cytosolic TrxR by 1 and 2}

To compare 1 and $\mathbf{2}$ with other ferrocenyl complexes, the potential effects on TrxR were investigated. Therefore, their inhibition of the isolated and purified cytosolic isoform of thioredoxin reductase (TrxR1) was measured. In accordance with previous results, ${ }^{28,36}$ we tested the action of $\mathbf{1}$ and $\mathbf{2}$ alone, and the compounds obtained by enzymatic oxidation by the $\mathrm{HRP} / \mathrm{H}_{2} \mathrm{O}_{2}$ mixture of $\mathbf{1}$ and $\mathbf{2}$, that is, $\mathbf{8} \mathrm{A}$ and $\mathbf{1 0}$, respectively. Compounds $\mathbf{1}$ and 2 only moderately inhibited cytosolic TrxR1 $\left(\mathrm{IC}_{50}=19.36 \mu \mathrm{M}\right.$ and $32.2 \mu \mathrm{M}$, respectively), whereas $\mathbf{8} \mathbf{A}$ and $\mathbf{1 0}$ were strong TrxR1 inhibitors $\left(\mathrm{IC}_{50}=27 \mathrm{nM}\right.$ and $31 \mathrm{nM}$, respectively; Figure 4). These values were lower than that found previously for $3\left(\mathrm{IC}_{50}=60 \mathrm{nM}\right) \cdot{ }^{28}$ No inhibition of glutathione reductase (GR) by 1, 2, 8 A and 10 was detected under similar conditions (Figure S4).

A

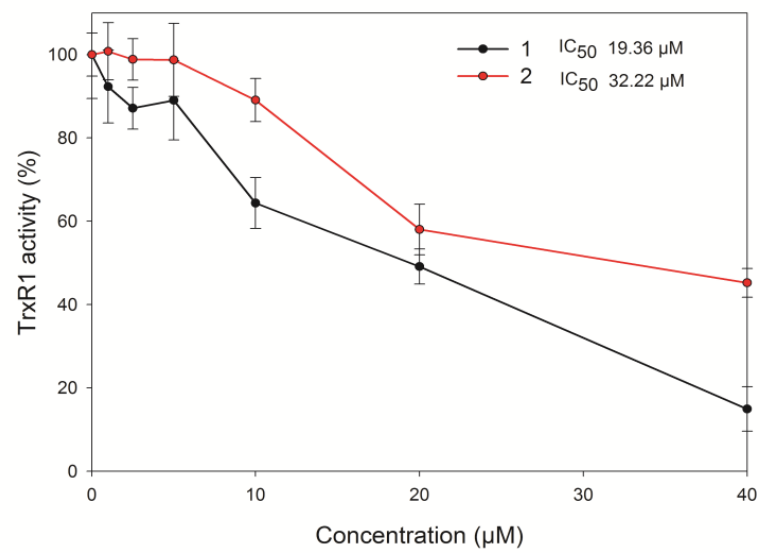

B

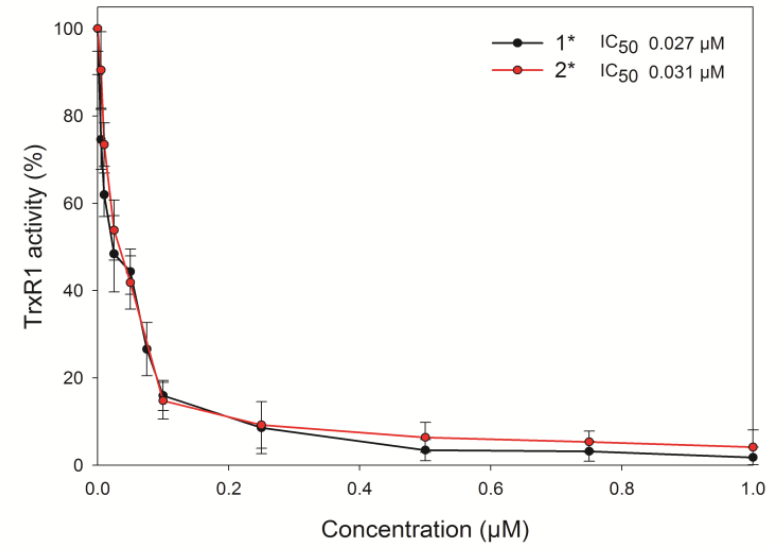

Figure 4. Concentration-dependent effects of A) $\mathbf{1}$ and $\mathbf{2}$, and B) $\mathbf{8} \mathbf{A}$ and $\mathbf{1 0}$ (obtained after oxidation of 1 and 2 by the $\mathrm{HRP} / \mathrm{H}_{2} \mathrm{O}_{2}$ mixture for $15 \mathrm{~min}$ ), on the cytosolic thioredoxin reductase activity (see the Experimental Section for details).

\section{Mechanism of inhibition of TrxR1 by 1 and 2}

The biotin-conjugated iodoacetamide (BIAM) assay was used in order to gain information on the residues involved in the inhibition of TrxR1 induced by 1, 2, $8 \mathrm{~A}$ and 10. This assay evaluates the ability of the complexes to interact with the thiol and/or selenol groups borne by the cysteine and selenocysteine residues of the enzyme. BIAM alkylates thiol and selenol groups depending on the $\mathrm{pH}$. At $\mathrm{pH} 6.0$, 
only selenocysteine and low pKa cysteine residues were alkylated, whereas at $\mathrm{pH}$ 8.5 , both selenocysteine and accessible cysteine residues were derivatised by BIAM. As shown in Figure 5, and in agreement with the TrxR1 inhibition pattern reported in Figure 4, both $\mathbf{8} \mathbf{A}$ and $\mathbf{1 0}$ prevented the alkylation of TrxR1 by BIAM at pH 6 (8 A being slightly more efficient than 10), indicating that both compounds were able to interact with the selenol group. At pH 8.5, full inhibition of BIAM alkylation by $\mathbf{8} \mathbf{A}$ and 10 occurred, indicating that they were also able to interact with accessible cysteine residues. In contrast, compounds 1 and 2 alone were barely effective. This type of result has been found previously for the ansa-ferrociphenol derivative $5{ }^{33}$ whereas only derivatisation of selenocysteine was observed with 3 . $^{26}$

A

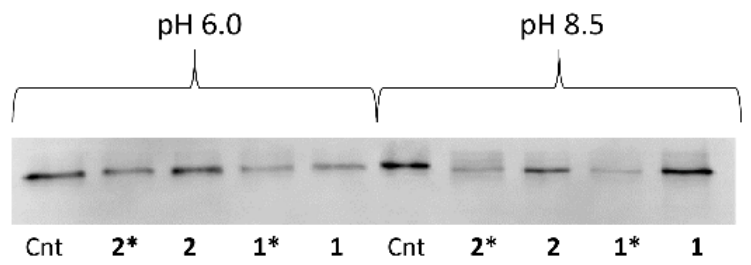

B

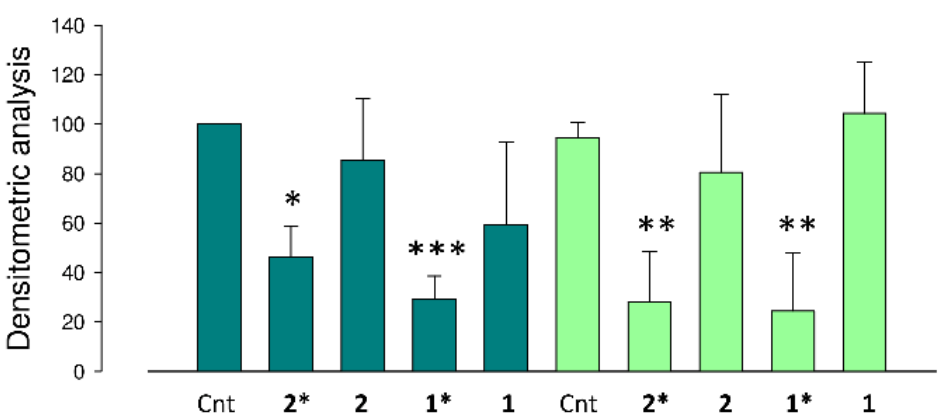

Figure 5. A) Biotinylated iodoacetamide (BIAM) assay of TrxR1 treated with 1, 8 A, 2 or 10. The complexes and their derivatives were incubated in the presence of a pre-reduced aliquot of TrxR1, as reported in the Experimental Section. Then, aliquots of the reaction mixture were added to $50 \mathrm{mM}$ BIAM in buffer at either pH $6.0(0.1 \mathrm{~m}$ HEPES-Tris) or $\mathrm{pH} 8.5(0.1 \mathrm{~m} \mathrm{Tris} \cdot \mathrm{HCl})$ to alkylate the remaining $\mathrm{SH} / \mathrm{SeH}$ groups. B) Densitometric analysis was performed using ImageJ software. ${ }^{*} \mathrm{p}<0.05$; ${ }^{* *} p<0.01 ;{ }^{* * *} p<0.001$.

\section{Antiproliferative activity of 1 and 2 on breast cancer cells}

The antiproliferative activity of $\mathbf{1}$ and $\mathbf{2}$ was measured in two breast cancer cell lines (MDA-MB-231 and MCF-7) after $72 \mathrm{~h}$ by MTT cell viability assay. Complex 1 
exhibited high antiproliferative activity on both cancer cells lines $\left(\mathrm{IC}_{50}=0.98\right.$ and 0.7 $\mu \mathrm{M}$, respectively), whereas complex 2 was markedly less cytotoxic $\left(\mathrm{IC}_{50}=69.8\right.$ and $25.5 \mu \mathrm{M}$, respectively). This result confirmed the low cytotoxicity previously described for $2 .^{24,25}$

\section{Inhibition of TrxR and GR induced by 1 and 2 in breast cancer cells}

Next, we evaluated the inhibitory effects of $\mathbf{1}$ and $\mathbf{2}$ on TrxR and GR activity in breast cancer cells. The enzymatic activity was measured in cell lysates, after incubation of cells with 1 or 2 at 20 or $40 \mu \mathrm{M}$ for $18 \mathrm{~h}$ (Figure 6). Complex 1 induced a moderate inhibition of TrxR (around $25 \%$ ) in MDA-MB-231 cells, but no inhibition in MCF-7 cells, whereas 2 had almost no effect on either cell line (Figure $6 \mathrm{~A}$ ). Compounds 1 and 2 had almost no effect on GR activity, at either concentration, in the two cell lines (Figure $6 \mathrm{~B}$ ). We also found that, under similar conditions $(15 \mu \mathrm{M}, 18 \mathrm{~h}), 1$ had no inhibitory effect on TrxR activity in Jurkat cells (Figure S5). Such different behaviour toward TrxR in cancer cells and in vitro on purified enzyme has been previously observed for the monophenol complex $4 .{ }^{26}$ Those observations were rationalised by the further conversion of its $\mathrm{QM}$ into an indene in protic solvent. Indeed, indene $\mathbf{1 4}$ is readily obtained by treating 1 with $\mathrm{Ag}_{2} \mathrm{O}$ as oxidant, followed by $\mathrm{ZnCl}_{2}$ as Lewis acid (Scheme 4). In addition, it was also identified as one of the metabolites during the microsomal oxidation of $\mathbf{1} .{ }^{37}$ In contrast to the QM, the indene cannot undergo Michael additions, which might explain the limited inhibition of TrxR by $\mathbf{1}$ in cancer cells. This result suggests that inhibition of TrxR does not play a major role in the cytotoxicity of 1 . 

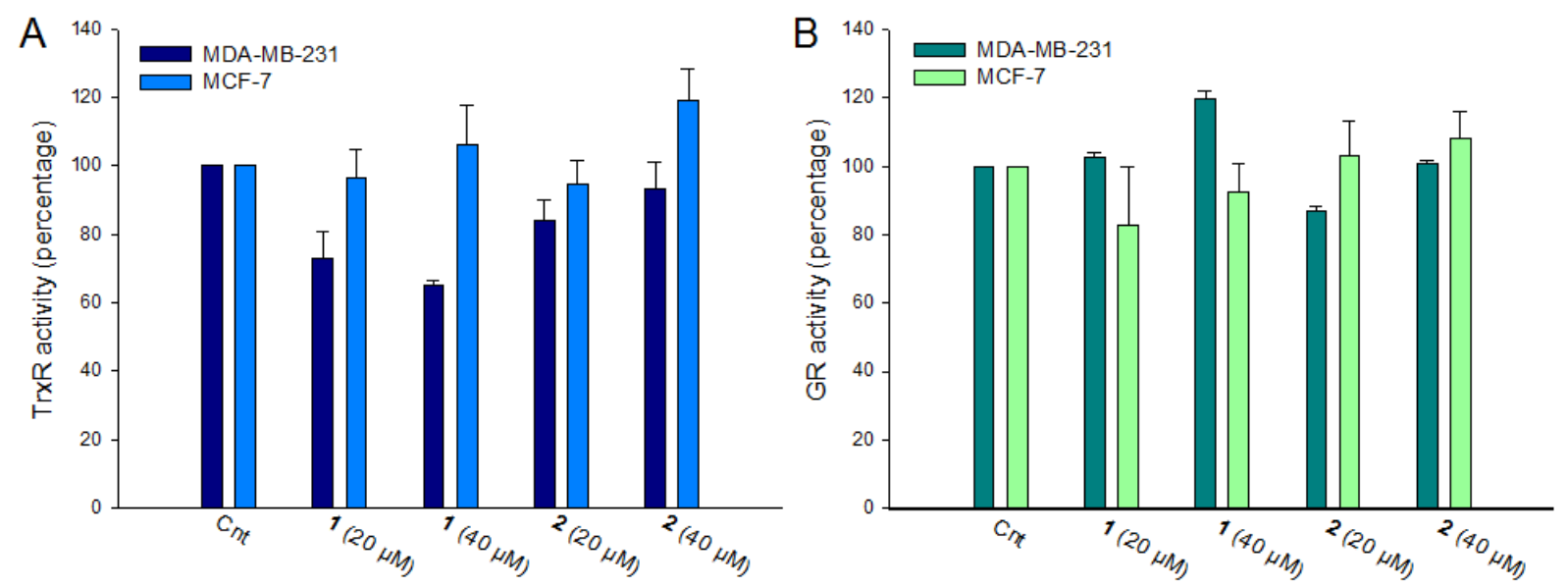

Figure 6. Effect of 1 and 2 on A) TrxR and B) GR enzyme activities in MDA-MB-231 and MCF-7 cells.

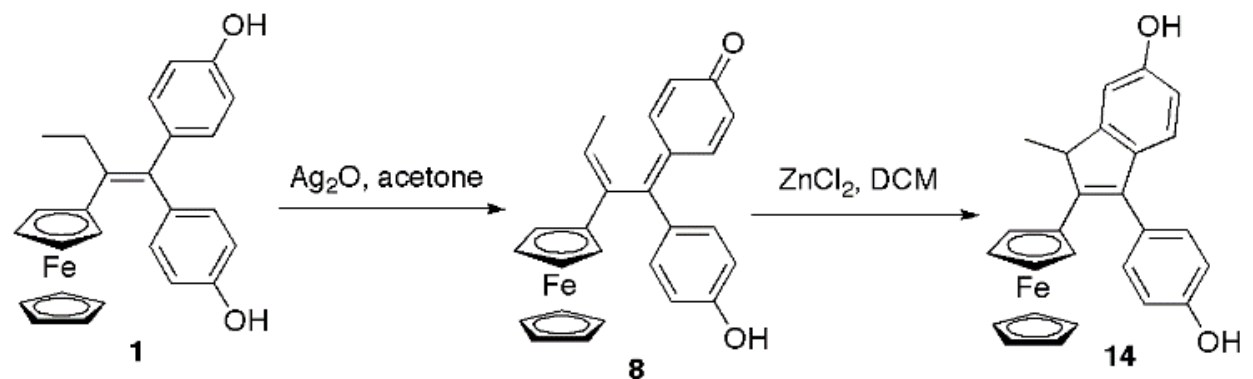

Scheme 4. Formation of the indene 14 from compound $1 .^{37}$

\section{Quantification of total thiols in cancer cells incubated with 1 or 2}

Intracellular sulfhydryl groups exist as thiol/thiolates or disulfide forms depending on the redox state of cells. In addition to protein thiols, the most abundant low-molecular-weight thiol in cells is glutathione, present at millimolar concentration. To investigate the action of $\mathbf{1}$ and $\mathbf{2}$ on the cellular redox balance, the total thiol content in cells treated with $40 \mu \mathrm{M}$ of 1 or 2 for $18 \mathrm{~h}$ was quantified (Table 1). The results showed that 1 induced a strong redox imbalance in MDA-MB-231 cells (44\% decrease of thiol content) and a less pronounced action in MCF-7 cells (18\% decrease of thiols), whereas 2 has almost no effect.

Table 1. Quantification of total thiols in control cells and cells incubated with 1 or $2(40 \mu \mathrm{M}, 18 \mathrm{~h})$.

\begin{tabular}{lcc}
\hline \multicolumn{3}{c}{ Total thiols (nmol per mg protein) } \\
\hline Compound & MDA-MB-231 & MCF-7 \\
\hline None & $38.2 \pm 7.8$ & $48.9 \pm 7.9$
\end{tabular}




$\begin{array}{lll}\mathbf{1} & 21.3 \pm 0.6 & 40.2 \pm 5.1 \\ \mathbf{2} & 40.6 \pm 5.1 & 46.1 \pm 7.8\end{array}$

Evaluation of the mitochondrial membrane potential in cancer cells treated with 1 or 2

The mitochondrial membrane potentials (MMPs) in MDA-MB-231 and MCF-7 cells were evaluated by flow cytometry using the fluorescent dye tetramethylrhodamine methyl ester (TMRM). Complex 1 induced a significant decrease of MMP in both MDA-MB-231 and MCF-7 cells (30\% of cells with low MMP after $18 \mathrm{~h}$ in the presence of $\mathbf{1}$ at $40 \mu \mathrm{M}$ ), whereas complex $\mathbf{2}$ was scarcely effective (Figure 7); 1 had no effect on Jurkat cells.

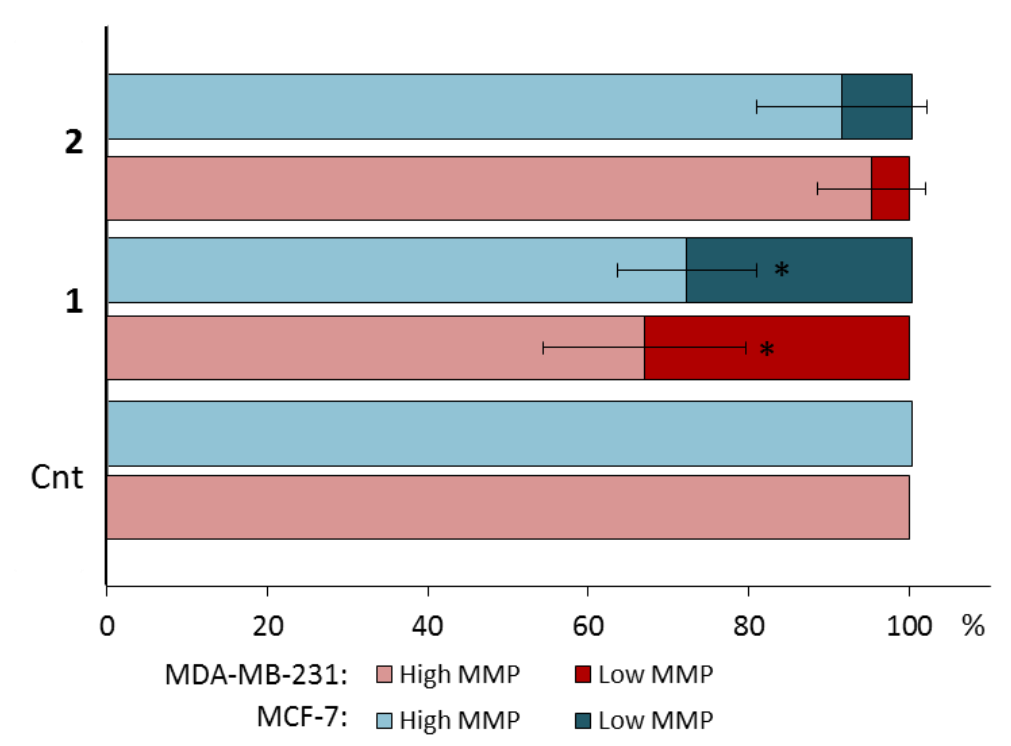

Figure 7. Evaluation of MMP in MCF-7 and MDA-MB-231 cells treated with 1 and $2(40 \mu \mathrm{M}, 18 \mathrm{~h})$ using the probe tetramethylrhodamine methyl ester. The percentage of cells with low and high MMP is shown. ${ }^{*} p<0.05$.

\section{Lipid peroxidation in MDA-MB-231 cells after treatment with 1 or 2}

To gain further insight into the mechanism of action of $\mathbf{1}$ and $\mathbf{2}$, we tested their ability to induce lipid peroxidation in MDA-MB-231 cells. Lipid peroxidation results from the 
attack on (poly)unsaturated lipids by reactive oxygen species (ROS) and is indicative of oxidative stress. The levels of malondialdehyde-the end product of lipid peroxidation-were measured by a fluorimetric assay. The results showed that $\mathbf{1}$ is able to induce a net $20-30 \%$ increase of malondialdehyde in a concentration-dependent fashion, whereas 2 had no effect (Figure 8).

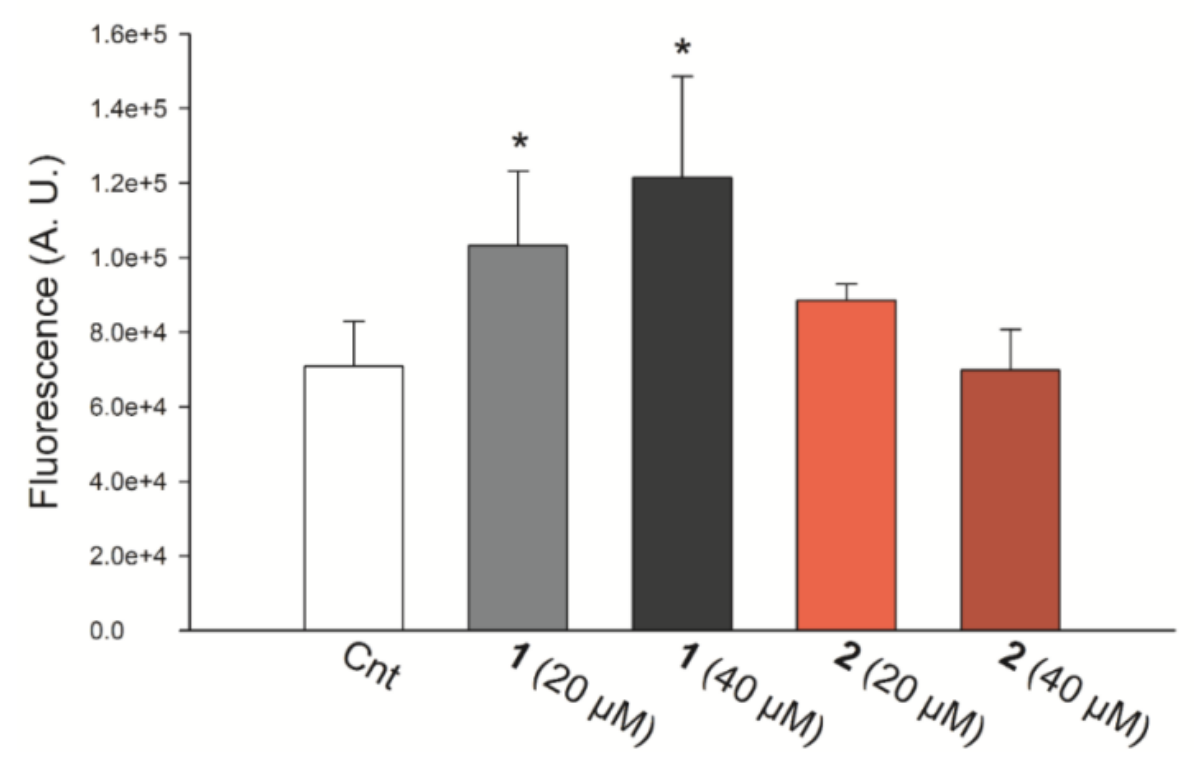

Figure 8. Lipid peroxidation induced by 1 and 2 in MDA-MB-231 cells. The amount of coloured adduct was measured with a fluorimetric assay (excitation: $530 \mathrm{~nm}$, emission: $590 \mathrm{~nm}$; see the Experimental Section for details). ${ }^{*} \mathrm{p}<0.05$.

\section{Comparison of the amount of iron in cells incubated with 1 or 2}

Iron was quantified by inductively coupled plasma optical emission spectroscopy (ICP-OES) after incubation of MDA-MB-231 and MCF-7 cell lysates with $40 \mu \mathrm{M} 1$ or 2 for $18 \mathrm{~h}$. The results (Table 2) show that the amount of iron found in cells incubated with 1 is significantly higher $(2.5$-fold) than with 2 . After subtraction of the endogenous iron contribution, the ratio between the amount of $\mathbf{1}$ and $\mathbf{2}$ in whole cells was raised to 2.9 in MCF-7 and 6.1 in MDA-MB-231 cells. This difference cannot be explained by different lipophilicity between the two complexes ( $\log \mathrm{Po} / \mathrm{w}=5.0$ for $\mathbf{1}$, 4.4 for 2), ${ }^{25,} 38$ but might be related to their difference in cytotoxicity. Indeed, after incubation for $18 \mathrm{~h}$, it is expected that the cytotoxic complex 1 has reacted with specific targets (proteins, DNA, etc.), resulting in its sequestration within cells. By 
contrast, the less cytotoxic compound $\mathbf{2}$ has reacted to a lesser extent, allowing its partial but significant release from the cells. 
Table 2. Amount of iron [ng per mg protein] ${ }^{[a]}$ in MCF-7 and MDA-MB-231 cells incubated with $\mathbf{1}$ or 2 $(40 \mu \mathrm{M})$ for $18 \mathrm{~h}$, quantified by ICP-OES.

\begin{tabular}{lcc}
\hline & MCF-7 & MDA-MB-231 \\
\hline Control cells & $120 \pm 36$ & $110 \pm 50$ \\
1 & $1070 \pm 245$ & $691 \pm 90$ \\
2 & $527 \pm 150$ & $298 \pm 42$ \\
\hline \multicolumn{2}{l}{${ }^{[a]}$ mean of two experiments \pm SD }
\end{tabular}

\section{Quantification of iron in individual cell compartments}

MDA-MB-231 and MCF-7 cells were incubated with $40 \mu \mathrm{M} 1$ for $18 \mathrm{~h}$. Cells were collected and fractionated into crude nuclear, mitochondrial and cytosolic fractions. Iron was quantified in each of these compartments by ICP_OES (Table 3 and Figure S7).

Table 3. Subcellular distribution of iron in MCF-7 or MDA-MB-231 cells incubated with $40 \mu \mathrm{M}$ of $\mathbf{1}$ for $18 \mathrm{~h}$, measured by ICP-OES.

\begin{tabular}{|c|c|c|c|}
\hline & Cytosolic fraction (\%) & Mitochondrial fraction (\%) & $\begin{array}{c}\text { Crude nuclear } \\
\text { fraction (\%) }\end{array}$ \\
\hline MCF-7 ${ }^{[a]}$ & 14 & 35 & 51 \\
\hline $\begin{array}{l}\text { MDA-MB- } \\
231^{[\mathrm{b}]}\end{array}$ & $10.8 \pm 0.4$ & $25 \pm 1.6$ & $64.2 \pm 1.3$ \\
\hline
\end{tabular}

The majority of the iron is located in the crude nuclear fraction. It is slightly higher for MDA-MB-231 cells than for MCF-7 (64.2\% vs. $51 \%)$. The amount of endogenous iron in this fraction is negligible ( $\approx 8-10 \%)$. The second largest concentration of iron was found in mitochondria, where it was slightly higher for MCF-7 than for MDA-MB-231 (35\% vs. $25 \%$ ). Once again, the contribution of endogenous iron was negligible $(\approx 10 \%)$. Finally, the amount of iron found in cytosol was low in both cell lines, with the proportion of endogenous iron ranging from $25-42 \%$, depending on the cell line (Figure S7). 


\section{Discussion}

The results obtained with $\mathbf{1}$ and $\mathbf{2}$, not only allow a better understanding of their mechanisms of action, but also explain the difference in their cytotoxicity.

The unique feature common to complexes $\mathbf{1}$ and $\mathbf{2}$ is their powerful inhibition of TrxR in vitro after enzymatic oxidation by the $\mathrm{HRP} / \mathrm{H}_{2} \mathrm{O}_{2}$ system $\left(\mathrm{IC}_{50} \approx 30 \mathrm{nM}\right)$. Furthermore, they both interact with its cysteine and selenocysteine residues. This activity is consistent with the fact that in both cases, enzymatic oxidation leads to the formation of a QM that can undergo a 1,8-Michael addition with the cysteine and selenocysteine residues of TrxR. In MDA-MB-231 cells, complex 1 induces only weak inhibition of TrxR and no inhibition in Jurkat cells. This result suggests that inhibition of $\operatorname{TrxR}$ is not a critical factor in the cytotoxicity of $\mathbf{1}$.

In terms of differences, we note that enzymatic oxidation of 1 by the $\mathrm{HRP} / \mathrm{H}_{2} \mathrm{O}_{2}$ system involves the ferrocenyl moiety and therefore contrasts with that of its organic analogue 6; moreover, oxidation of $\mathbf{2}$ does not proceed by initial reaction at the iron centre but instead mirrors that of the organic compound 7 . This difference appears to be crucial, as the oxidation of Fell to Felll, which constitutes the first step of the activation of $\mathbf{1}$ (and $\mathbf{3}$ ) and is accompanied by the production of ROS in variable amounts, ${ }^{39,40}$ is not observed with $\mathbf{2} .{ }^{17}$ It is confirmed here by the effect of 1 on lipid peroxidation, which was not observed with $\mathbf{2}$. This process might be associated with the production of ROS, which seemingly play an important role in the cytotoxicity of $\mathbf{1}$. Indeed, on MCF-7 cells, co-incubation of 1 with $\mathrm{N}$-acetylcysteine, a known antioxidant ROS scavenger, resulted in the loss of its cytotoxic activity (Figure S8).

We have previously demonstrated that the cytotoxicity of ferrocifens is associated with their unique redox properties and the presence of a ferrocenyl-double bondphenol motif. ${ }^{14,17}$ In the monophenolic complex 4, or the diphenolic complex 2, the ferrocenyl and phenol substituents can in principle adopt either trans $[(E)-4,(E)-2)$ or cis [(Z)-4, (Z)-2] configurations (Scheme 5). However, as noted above, $\mathbf{2}$ is found only as the $Z$ isomer. 

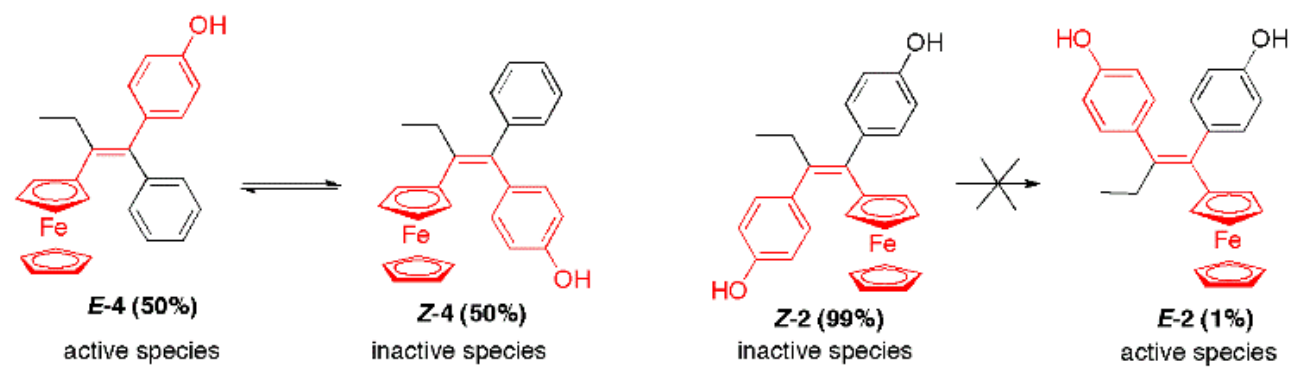

Scheme 5. Consequences of the $E / Z$ isomerisation of 4 and of the failure of 2 to undergo $E / Z$ isomerisation.

It therefore seems plausible to hypothesise that only the trans form of the complexes, which exists for $\mathbf{4}$ and $\mathbf{1}$, but not for $\mathbf{2}$, facilitates the oxidation of Fell to Felll, with consequent production of ROS in the cell. This hypothesis also explains the twofold difference in cytotoxicity between $\mathbf{1}$ and $\mathbf{4}(0.6$ and $1.13 \mu \mathrm{M}) .{ }^{34}$

Because of the approximately equal distribution of the cis and trans forms of the monophenol 4 , only $50 \%$ of the active $E$ form is initially present in solution. Of course, in the case of the diphenol $\mathbf{1}$, every molecule possesses a phenol substituent trans to the ferrocenyl moiety. This assumption is in accordance with the observation that all QMs obtained by the chemical oxidation of ferrocifens that are sufficiently stable to have been characterised unequivocally are exclusively the $E$ isomers. This was initially confirmed by the X-ray crystal structure of a QM stabilised by the incorporation of two methyl substituents ortho to the carbonyl group, ${ }^{13}$ and by another very recent study in which several QMs stabilised by an atypical lone pair- $\pi$ interaction were also structurally characterised. ${ }^{41}$

This result can be explained as follows: let us consider the mechanism of the stepwise oxidation process to form the QM (Scheme S1). To allow delocalisation of the initially formed radical cation from the ferrocenyl to the hydroxy substituent on the phenol, and subsequently from the QM back to the carbon atom adjacent to the ferrocenyl, the connecting framework must be almost planar to favour orbital overlap through the $\pi$ system. This is ideal in the $E$ isomer but would be impossible in the $Z$ form, because co-planarity of the $\mathrm{C}_{5} \mathrm{H}_{5}$ ring of the ferrocenyl unit and the cis-configured QM ring would engender serious steric problems. 
In summary, the lower cytotoxicity of $\mathbf{2}$ can be explained by the fact that the $Z$ configuration of complex $\mathbf{2}$ does not allow expression of the singular redox effects of ferrocene, which are observed only if the sequence is trans-[ferrocene-double bondphenol]. Molecule 2 can indeed undergo oxidation, but its initial behaviour parallels that of its organic counterpart by forming diquinone 9 , rather than exhibiting the redox effect of ferrocene, which is the origin of the cytotoxicity of $\mathbf{1}$.

The results obtained also make it possible to compare the mechanism of action of $\mathbf{1}$ with that of the tamoxifen-like complex 3 (Figure 1); in particular, they highlight two essential differences. Firstly, 1 barely inhibits thioredoxin reductase activity in Jurkat cells (Figure S6), whereas 3 inhibits it significantly (100\% of inhibition with $15 \mu \mathrm{M}$ 3). ${ }^{28}$ This behaviour is attributed to the cyclisation, in cells, of the QM 8 to form the corresponding indene 14 (Scheme 4). ${ }^{26}$ Secondly, 1 does not induce MMP variation in Jurkat cells. This indicates the non-involvement of mitochondria in the cytotoxicity of $\mathbf{1}$, in contrast to $3,^{28}$ thus confirming the essential role played, in this interaction, by the dimethylaminopropyl chain, which confers on $\mathbf{3}$ the character of a lipophilic cation. ${ }^{28}$ Given this observation, the quantities of iron in different cellular compartments (mitochondria, crude nuclear extract, cytosol) might be a surprising result. In fact, a significant percentage of the iron is found in the mitochondria of cells incubated with 1 (35\% in MCF-7 cells, $25 \%$ in MDA-MB-231 cells, Table 3), although the product does not have an effect at $40 \mu \mathrm{M}$ concentration. This confirms the fact, previously observed, that the intracellular sites where complexes are highly concentrated are not necessarily those where they exert their action, but the effects are instead related to their lipophilicity. ${ }^{42,}{ }^{43}$ The quantities of iron found are also similar to those obtained for 4 in Jurkat cells (37\% in the mitochondria of Jurkat cells), ${ }^{31}$ a complex whose lipophilicity is close to that of $1\left(\log \mathrm{P}_{\mathrm{o} / \mathrm{w}} \approx 4.5\right)$.

\section{Conclusion}

Comparisons of the reactivity and the biological behaviour of diphenols $\mathbf{1}$ and $\mathbf{2}$ make it possible to better understand their mechanisms of action by highlighting the importance of the trans configuration in the ferrocenyl-double bond-phenol sequence for mediating the cytotoxicity of ferrocifens. It also confirms that, although 1 and 3 have similar cytotoxicities on MDA-MB-231 cells, their mechanism of action 
differs in some respects. Indeed, in addition to the limited inhibition of $\operatorname{TrxR}$ in the cells, we report here that $\mathbf{1}$ has only a slight effect on mitochondria. This leads to the idea that its mechanism of action is essentially associated with a redox imbalance, as demonstrated by lipid peroxidation and thiol oxidation studies, whereas that of $\mathbf{3}$ implies an additional effect on mitochondria. Eventually, comparison of the biological behaviour of the highly cytotoxic complex $\mathbf{1}$, with that of the poorly cytotoxic complex $\mathbf{2}$, let us move forward with respect to understanding the mechanism of action of $\mathbf{1}$, one hit in the ferrocifen series.

\section{Experimental Section}

\section{Materials}

Compounds 1 and 2 were synthesised according to literature procedures. ${ }^{19,25}$ Stock solutions $(10 \mathrm{mM})$ were prepared in DMSO.

\section{Enzymatic oxidation with the mixture $\mathrm{HRP} / \mathrm{H}_{2} \mathrm{O}_{2}$}

Enzymatic oxidation of the compounds $(25-50 \mu \mathrm{M})$ by $\mathrm{HRP}(46 \mathrm{nM})$ and $\mathrm{H}_{2} \mathrm{O}_{2}(200$ $\mu \mathrm{M})$ was performed at $\mathrm{pH} 8.1$ in buffer $(0.2 \mathrm{~m}$ Tris. $\mathrm{HCl}, 1 \mathrm{mM} \mathrm{EDTA})$ containing $10 \%$ DMSO. HRP ( $40 \mu \mathrm{L}$ of $1.14 \mu \mathrm{M}$ solution) and $\mathrm{H}_{2} \mathrm{O}_{2}$ (20 $\mu \mathrm{L}$ of $10 \mathrm{mM}$ solution) were pre-incubated for $5 \mathrm{~min}$ and then added to the solution of the compound $(940 \mu \mathrm{L})$. The solution was immediately transferred to a cuvette and the UV/Vis spectrum was recorded between 250 and 650 or $750 \mathrm{~nm}$ on a Cary 50 spectrometer (Varian, Palo Alto, $C A)$. Rate constant $k_{\text {obs }}$ of oxidation of 1 was calculated by fitting $O D_{560 n m}$ versus time data according to the first-order law Equation 1 with KaleidaGraph software $\left(C_{0}\right.$ corresponds to the absorbance at infinite time, while $C_{1}$ is the difference between absorbance at 0 time and absorbance at infinite time).

$$
\mathrm{OD}=C_{0}+C_{1} \times \exp \left(-\mathrm{k}_{\mathrm{obs}} \times \mathrm{t}\right)
$$

\section{TrxR1 activity in vitro}


Thioredoxin reductase activity was determined by measuring the ability of TrxR1 to reduce 5,5'-dithiobis(2-nitrobenzoic acid) (DTNB) in the presence of NADPH. Aliquots of highly purified TrxR1 in Tris. $\mathrm{HCl}$ buffer $(0.2 \mathrm{M}, \mathrm{pH} 8.1)$ containing EDTA (1 mM) and NADPH $(0.25 \mathrm{mM})$ were preincubated for $5 \mathrm{~min}$ with the compounds. Then, the reaction was initiated with DTNB $(1 \mathrm{mM})$ and monitored spectrophotometrically at $412 \mathrm{~nm}$ for approximately $10 \mathrm{~min}$. For the oxidation of 1 and 2 in order to obtain ferrociphenol derivatives, freshly prepared compounds, at increasing concentrations, were incubated for $15 \mathrm{~min}$ in Tris. $\mathrm{HCl}$ buffer $(0.2 \mathrm{M}$, pH 8.1) containing EDTA (1 mM), $\mathrm{H}_{2} \mathrm{O}_{2}(0.1 \mathrm{mM})$ and HRP $(22 \mathrm{nM})$. Then, TrxR1 and NADPH $(0.25 \mathrm{mM})$ were added and mixtures were incubated for another $5 \mathrm{~min}$. Finally, the reaction was initiated with DTNB (1 mM) and monitored spectrophotometrically at $412 \mathrm{~nm}$ for approximately 10 $\min$.

\section{BIAM assay}

Compounds 1 and $2(4 \mu M)$ were treated with a mixture of HRP $(22 n M)$ and $\mathrm{H}_{2} \mathrm{O}_{2}$ $(0.1 \mathrm{mM})$ for $15 \mathrm{~min}$. Then, TrxR1 $(1 \mu \mathrm{M})$ pre-reduced with NADPH $(60 \mu \mathrm{M})$, was incubated for $30 \mathrm{~min}$ with the compounds or their derivatives $(2 \mu \mathrm{M})$ in Tris. $\mathrm{HCl}$ buffer $(50 \mathrm{mM}, \mathrm{pH}$ 7.4) containing NADPH $(200 \mu \mathrm{M})$ and EDTA (1 mM). After incubation, a sample of the reaction mixture $(8 \mu \mathrm{L})$ was added to BIAM $(100 \mathrm{mM}, 8 \mu \mathrm{L})$ in Tris $\cdot \mathrm{HCl}$ (0.1 M, pH 8.5) or HEPES-Tris $(0.1 \mathrm{M}, \mathrm{pH} 6.0)$ buffers. Samples were incubated at $\mathrm{RT}$ for an additional $30 \mathrm{~min}$ to allow BIAM alkylation of free $\mathrm{SH} / \mathrm{SeH}$ groups of the enzyme. Then, BIAM-modified enzyme was subjected to SDS-PAGE (10\% gel) and transferred to a nitrocellulose membrane. BIAM-labelled enzyme was detected using HRP-conjugated streptavidin and enhanced chemiluminescence detection.

\section{MTT proliferation assay}

Cells $\left(5 \times 10^{3}\right)$ were seeded in a 96-well plate and treated with the compounds dissolved in DMSO. After $72 \mathrm{~h}$, the medium was removed and MTT solution (0.5 $\left.\mathrm{mg} \mathrm{mL}^{-1}, 100 \mu \mathrm{L}\right)$ in PBS (1x) was added. After $3 \mathrm{~h}$ in the dark at $37^{\circ} \mathrm{C}$ and $5 \% \mathrm{CO}_{2}$, the MTT solution was gently aspirated and the reaction was quenched with 
isopropanol/DMSO $(9: 1,100 \mu \mathrm{L})$. Then, the absorbance was recorded (A595-690) using a plate reader (Tecan Infinite M200 PRO, Männedorf, Switzerland).

\section{TrxR and GR activities in cell lysates}

Cells $\left(1 \times 10^{6}\right)$ were incubated for $18 \mathrm{~h}$ in the presence of the compounds and then harvested and washed with PBS. Each sample was lysed with a modified radioimmunoprecipitation assay (RIPA) buffer: $\mathrm{NaCl}(150 \mathrm{mM})$, Tris. $\mathrm{HCl}(50 \mathrm{mM})$, EDTA ( $1 \mathrm{mM}), 1 \%$ Triton X-100, $0.1 \%$ SDS, $0.5 \%$ sodium deoxycholate, NaF (1 $\mathrm{mM}$ ) and an antiprotease cocktail (Complete, Roche, Mannheim, Germany) containing phenylmethylsulfonyl fluoride (PMSF, $0.1 \mathrm{mM}$ ). After $40 \mathrm{~min}$ at $4{ }^{\circ} \mathrm{C}$, the lysates were centrifuged at $12000 \mathrm{~g}$, to discard the debris, and tested for total TrxR activity. The reaction was started by the addition of DTNB $(0.1 \mathrm{M})$. The absorbance of the DTNB reduction product was monitored at $412 \mathrm{~nm}$ at $25^{\circ} \mathrm{C}$. GR activity of cell lysates was measured in Tris. $\mathrm{HCl}$ buffer $(0.2 \mathrm{M}, \mathrm{pH}$ 8.1) containing EDTA (1 mM) and NADPH $(0.25 \mathrm{mM})$. The assay was initiated by addition of glutathione disulfide ( 1 $\mathrm{mM}$ ) and monitored spectrophotometrically at $340 \mathrm{~nm}$.

\section{Total thiol assay}

MDA-MB-231 and MCF-7 cells $\left(3.5 \times 10^{5}\right)$ were seeded in six-well plates and treated with the compounds. After $18 \mathrm{~h}$, the plates were washed with PBS $(1 \times, 1 \mathrm{~mL})$. Cells were then dissolved with Tris. $\mathrm{HCl}(0.2 \mathrm{M}, \mathrm{pH} 8.1,1 \mathrm{~mL})$, EDTA $(5 \mathrm{mM})$ and guanidine (7.2 M). The reaction was started by the addition of DTNB $(0.1 \mathrm{M})$. The absorbance of the product of DTNB reduction was monitored at $412 \mathrm{~nm}$ at $25^{\circ} \mathrm{C}$.

\section{Mitochondrial membrane potential assay}

Cells $\left(1 \times 10^{6}\right)$ were seeded in $25 \mathrm{~cm}^{2}$ flasks and then treated with the compounds for $18 \mathrm{~h}$. Subsequently, the cells were washed with PBS $(1 \mathrm{x})$ and glucose $(10 \mathrm{mM})$, trypsinised and centrifuged at $500 \mathrm{~g}$ for $5 \mathrm{~min}$. Then, cells $\left(2.5 \times 10^{5}\right.$ per tube) were resuspended in PBS $(1 \times)$ and glucose $(10 \mathrm{mM})$ and incubated with the fluorescent probe TMRM ( $25 \mathrm{nM}$, Thermo Fisher Scientific, Waltham, MA) for 20 min. FACS 
analysis of TMRM was performed on a FACSCanto II flow cytometer (Becton Dickinson, Franklin Lakes, NJ).

\section{Lipid peroxidation assay}

Cells $\left(1 \times 10^{6}\right)$ were treated with compounds at different concentrations for $18 \mathrm{~h}$. Next, cells were washed with PBS and disrupted with $\mathrm{H}_{2} \mathrm{SO}_{4}(50 \mathrm{mM}, 1 \mathrm{~mL})$ and $10 \%$ phosphotungstic acid $(150 \mu \mathrm{L})$ for $10 \mathrm{~min}$ at RT. Then, cells were scraped and centrifuged at $15600 \mathrm{~g}$ for $10 \mathrm{~min}$ at $4^{\circ} \mathrm{C}$. The obtained pellets were washed with $\mathrm{H}_{2} \mathrm{SO}_{4}(50 \mathrm{mM}, 1 \mathrm{~mL})$ and $10 \%$ phosphotungstic acid $(150 \mu \mathrm{L})$. Samples were kept at RT for $5 \mathrm{~min}$ and centrifuged at $15600 \mathrm{~g}$ for $10 \mathrm{~min}$ at $4{ }^{\circ} \mathrm{C}$. Next, the pellets were dissolved with $0.25 \%$ Nonidet P-40 $(350 \mu \mathrm{L})$ containing $0.01 \%$ butylhydroxytoluene and $0.17 \%$ thiobarbituric acid, and incubated at $95^{\circ} \mathrm{C}$ for $60 \mathrm{~min}$. Samples, were cooled on ice for $5 \mathrm{~min}$ and centrifuged at $15600 \mathrm{~g}$ for $10 \mathrm{~min}$. The supernatants were added to $n$-butanol (400 $\mu \mathrm{L})$, vigorously mixed and centrifuged at $15600 \mathrm{~g}$ for $15 \mathrm{~min}$. The fluorescence of the upper phase was analysed $(E x=530 \mathrm{~nm}, E m=590$ $\mathrm{nm}$ ) using a plate reader (Tecan Infinite M200 PRO, Männedorf, Switzerland). The discarded pellets were solubilised and subjected to protein determination.

\section{Preparation of cellular sub-fractions}

Cells were sub-fractionated by essentially following a published protocol. $^{28}$ In brief, cells $\left(3 \times 10^{7}\right)$ were collected, washed with PBS and subjected to hypo-osmotic treatment with Tris. $\mathrm{HCl}$ buffer $(10 \mathrm{mM}, \mathrm{pH} 7.5,2 \mathrm{~mL})$ containing $\mathrm{NaCl}(10 \mathrm{mM})$ and $\mathrm{MgCl}_{2}(1.5 \mathrm{mM})$ for $5 \mathrm{~min}$ and gently homogenised using a Dounce tissue grinder. Then, Tris. $\mathrm{HCl}$ buffer $(12.5 \mathrm{mM}, \mathrm{pH} 7.5,1.4 \mathrm{~mL})$ containing mannitol (525 mM), sucrose $(175 \mathrm{mM})$ and EDTA $(2.5 \mathrm{mM})$ was rapidly added. The homogenate was diluted to a final volume of $5 \mathrm{~mL}$ with mannitol $(210 \mathrm{mM})$, sucrose $(70 \mathrm{mM})$, EDTA (1 $\mathrm{mM})$, Tris. $\mathrm{HCl}$ buffer $(5 \mathrm{mM}, \mathrm{pH} 7.5)$ and subjected to differential centrifugation. The first step was carried out at $1300 \mathrm{~g}$ for $5 \mathrm{~min}$ at $4^{\circ} \mathrm{C}$ to discard nuclei and non-disrupted cells. The mitochondrial fraction was isolated from the supernatant at $15800 \mathrm{~g}$ for $15 \mathrm{~min}$ at $4^{\circ} \mathrm{C}$ and washed twice. The crude soluble supernatant obtained from the mitochondria isolation step was further centrifuged at $105000 \mathrm{~g}$ for 
$15 \mathrm{~min}$ at $4{ }^{\circ} \mathrm{C}$ to obtain the cytosolic fraction. Mitochondrial fractions were lysed using a modified RIPA buffer containing Tris. $\mathrm{HCl}(50 \mathrm{mM}, \mathrm{pH} 7.4), \mathrm{NaCl}(150 \mathrm{mM})$, EDTA $(1 \mathrm{mM}), 1 \%$ Triton X100, $0.1 \%$ SDS, $0.5 \%$ DOC and NaF ( $1 \mathrm{mM})$, supplemented with an antiprotease cocktail and PMSF $(0.1 \mathrm{mM})$, and subjected to protein determination using the Lowry assay. ${ }^{44}$ The presence of cytochrome oxidase and cytochrome $\mathrm{c}$ as mitochondrial markers was assessed by western blot analysis of the mitochondrial fraction.

\section{Iron assay by ICP-OES}

Cells incubated for $18 \mathrm{~h}$ in the presence of the compounds $(40 \mu \mathrm{M})$ were collected as cell lysates (starting from $1 \times 10^{6}$ cells) or subjected to cell fractionation (starting from $24 \times 10^{6}$ cells) as described in a previous section. Cell lysates, mitochondria and crude nuclei fractions were dissolved in concentrated nitric acid $(70 \%$, ACS grade, $0.286 \mathrm{~mL}$ ) and digested at $60^{\circ} \mathrm{C}$ in an ultrasonic bath for $1 \mathrm{~h}$. Then the sample volume was adjusted to $10 \mathrm{~mL}$ by addition of water (final concentration of $\mathrm{HNO}_{3}$ in the sample was $2 \%$ ). The cytosol samples were adjusted to $2 \% \mathrm{HNO}_{3}$ by addition of proper volumes of $\mathrm{HNO}_{3}$ and water (final volume of $10 \mathrm{~mL}$ Milli-Q grade water) and kept at $4{ }^{\circ} \mathrm{C}$ for $48 \mathrm{~h}$. Samples were clarified by brief centrifugation at $2600 \mathrm{~g}$ for 5 min and filtered on a $0.22 \mu \mathrm{m}$ PES membrane. Quantification of iron was performed at $238.204 \mathrm{~nm}$ using an Agilent 5100 instrument (Santa Clara, CA). Iron standards were prepared from a $1000 \mathrm{ppm}$ stock solution (Iron standards for ICP, Fluka). The concentrations used for calibration were $0,7.8,15.6,31.2,62.5,125,250$ and 500 $\mathrm{ppb}$. Measurements were performed in triplicate in two or three sets of independent experiments. ICP-OES experiments were performed on an Agilent 5100 SVDV at the ALIPP6 laboratory (ISTeP, Sorbonne Université).

\section{Acknowledgements}

M.P.R. and V.S. acknowledge BIRD187299/18 granted by the University of Padova (Italy). We thank Sébastien Blanchard (IPCM, Sorbonne Université) for the EPR measurements. 


\section{Conflict of interest}

The authors declare no conflict of interest.

\section{References}

1 N. P. E. Barry, P. J. Sadler, Chem. Commun. 2013, 49, 5106-5131.

2 G. Gasser, I. Ott, N. Metzler-Nolte, J. Med. Chem. 2011, 54, 3-25.

3 E. Wong, C. M. Giandomenico, Chem. Rev. 1999, 99, 2451-2466.

4 C. G. Hartinger, P. J. Dyson, Chem. Soc. Rev. 2009, 38, 391-401.

5 P. Y. Zhang, P. J. Sadler, J. Organomet. Chem. 2017, 839, 5-14.

6 B. Albada, N. Metzler-Nolte, Chem. Rev. 2016, 116, 11797-11839.

7 S. M. Meier-Menches, C. Gerner, W. Berger, C. G. Hartinger, B. K. Keppler, Chem. Soc. Rev. 2018, 47, 909-928.

8 E. A. Hillard, A. Vessières, G. Jaouen in Medicinal Organometallic Chemistry, Springer-Verlag, Berlin, 2010, pp. 81-117.

9 G. Jaouen, S. Top in Advances in Organometallic Chemistry and Catalysis, Wiley, Hoboken, 2014, pp. 561-580.

10 G. Jaouen, A. Vessières, S. Top, Chem. Soc. Rev. 2015, 44, 8802-8817.

11 A. Vessières, J. Organomet. Chem. 2013, 734, 3-16.

12 A. Vessieres in Metal-Based Anticancer Agents, Royal Society of Chemistry, Cambridge, 2019, pp. 62-90.

13 D. Hamels, P. M. Dansette, E. A. Hillard, S. Top, A. Vessières, P. Herson, G. Jaouen, D. Mansuy, Angew. Chem. Int. Ed. 2009, 48, 9124-9126.

14 P. Messina, E. Labbé, O. Buriez, E. A. Hillard, A. Vessières, D. Hamels, S. Top, G. Jaouen, Y. M. Frapart, D. Mansuy, C. Amatore, Chem. Eur. J. 2012, 18, 6581-6587.

15 Y. Wang, M. A. Richard, S. Top, P. M. Dansette, P. Pigeon, A. Vessières, D. Mansuy, G. Jaouen, Angew. Chem. Int. Ed. 2016, 55, 10431-10434.

16 Y. Wang, P. M. Dansette, P. Pigeon, S. Top, M. J. McGlinchey, D. Mansuy, G. Jaouen, Chem. Sci. 2018, 9, 70-78.

17 E. A. Hillard, A. Vessières, L. Thouin, G. Jaouen, C. Amatore, Angew. Chem. Int. Ed. 2006, 45, 285-290. 
18 G. Jaouen, S. Top, A. Vessières, G. Leclercq, J. Quivy, L. Jin, A. Croisy, C. R. Acad. Sci., Ser. Ilc: Chim. 2000, 3, 89-93.

19 S. Top, A. Vessières, G. Leclercq, J. Quivy, J. Tang, J. Vaissermann, M. Huché, G. Jaouen, Chem. Eur. J. 2003, 9, 5223-5236.

20 M. Görmen, P. Pigeon, S. Top, E. A. Hillard, M. Huché, C. G. Hartinger, F. de Montigny, M.-A. Plamont, A. Vessières, G. Jaouen, ChemMedChem 2010, 5, 2039-2050.

21 E. Allard, C. Passirani, E. Garcion, P. Pigeon, A. Vessières, G. Jaouen, J. P. Benoit, J. Controlled Release 2008, 130, 146-153.

22 C. Bruyère, V. Mathieu, A. Vessières, P. Pigeon, S. Top, G. Jaouen, R. Kiss, J. Inorg. Biochem. 2014, 141, 144-151.

23 Q. Michard, G. Jaouen, A. Vessières, B. A. Bernard, J. Inorg. Biochem. 2008, 102, 1980-1985.

24 Y. L. K. Tan, P. Pigeon, E. A. Hillard, S. Top, M.-A. Plamont, A. Vessières, M. J. McGlinchey, H. Mueller-Bunz, G. Jaouen, Dalton Trans. 2009, 10871-10881.

25 A. Vessières, S. Top, P. Pigeon, E. A. Hillard, L. Boubeker, D. Spera, G. Jaouen, J. Med. Chem. 2005, 48, 3937-3940.

26 A. Citta, A. Folda, A. Bindoli, P. Pigeon, S. Top, A. Vessières, M. Salmain, G. Jaouen, M. P. Rigobello, J. Med. Chem. 2014, 57, 8849-8859.

27 V. Scalcon, A. Bindoli, M. P. Rigobello, Free Radical Biol. Med. 2018, 127, 6279.

28 V. Scalcon, M. Salmain, A. Folda, S. Top, P. Pigeon, H. Z. S. Lee, G. Jaouen, A. Bindoli, A. Vessières, M. P. Rigobello, Metallomics 2017, 9, 949-959.

29 Ö. Karaca, V. Scalcon, S. M. Meier-Menches, R. Bonsignore, J. M. J. L. Brouwer, F. Tonolo, A. Folda, M. P. Rigobello, F. E. Kühn, A. Casini, Inorg. Chem. 2017, 56, 14237-14250.

30 E. Schuh, C. Pflüger, A. Citta, A. Folda, M. P. Rigobello, A. Bindoli, A. Casini, F. Mohr, J. Med. Chem. 2012, 55, 5518-5528.

31 V. W. Winkler, M. A. Nyman, R. S. Egan, Steroids 1971, 17, 197.

32 Y. Ortin, J. Grealis, C. Scully, H. Muller-Bunz, A. R. Manning, M. J. McGlinchey, J. Organomet. Chem. 2004, 689, 4683-4690.

33 V. Scalcon, A. Citta, A. Folda, A. Bindoli, M. Salmain, I. Ciofini, S. Blanchard, J. D. Cazares-Marinero, Y. Wang, P. Pigeon, G. Jaouen, A. Vessières, M. P. Rigobello, J. Inorg. Biochem. 2016, 165, 146-151. 
34 H. Z. S. Lee, O. Buriez, F. Chau, E. Labbé, R. Ganguly, C. Amatore, G. Jaouen, A. Vessières, W. K. Leong, S. Top, Eur. Inorg. Chem. 2015, 4217-4225.

35 G. H. Degen, J. A. McLachlan, Chem.-Biol. Interact. 1985, 54, 363-375.

36 V. Scalcon, S. Top, H. Z. S. Lee, A. Citta, A. Folda, A. Bindoli, W. K. Leong, M. Salmain, A. Vessières, G. Jaouen, M. P. Rigobello, J. Inorg. Biochem. 2016, 160, 296-304.

37 M.-A. Richard, D. Hamels, P. Pigeon, S. Top, P. M. Dansette, H. Z. S. Lee, A. Vessières, D. Mansuy, G. Jaouen, ChemMedChem 2015, 10, 981-990.

38 E. A. Hillard, A. Vessières, S. Top, P. Pigeon, K. Kowalski, M. Huché, G. Jaouen, J. Organomet. Chem. 2007, 692, 1315-1326.

39 C. Lu, J. M. Heldt, M. Guille-Collignon, F. Lemaitre, G. Jaouen, A. Vessières, C. Amatore, ChemMedChem 2014, 9, 1286-1293.

40 A. Vessières, C. Corbet, J. M. Heldt, N. Lories, N. Jouy, I. Laios, G. Leclercq, G. Jaouen, R. A. Toillon, J. Inorg. Biochem. 2010, 104, 503-511.

41 Y. Wang, P. Pigeon, S. Top, J. Sanz Garcia, C. Troufflard, I. Ciofini, M. J. McGlinchey, G. Jaouen, Angew. Chem. Int. Ed. 2019, 58, 8421-8425.

42 S. Clède, F. Lambert, C. Sandt, S. Kascakova, M. Unger, E. Harte, M. A. Plamont, R. Saint-Fort, A. Deniset-Besseau, Z. Gueroui, C. Hirschmugl, S. Lecomte, A. Dazzi, A. Vessières, C. Policar, Analyst 2013, 138, 5627-5638.

43 F. Fus, Y. Yang, H. Z. S. Lee, S. Top, M. Carriere, A. Bouron, A. Pacureanu, J. C. da Silva, M. Salmain, A. Vessières, P. Cloetens, G. Jaouen, S. Bohic, Angew. Chem. Int. Ed. 2019, 58, 3461-3465.

44 O. H. Lowry, N. J. Rosebrough, A. L. Farr, R. J. Randall, J. Biol. Chem. 1951, 193, 265-275. 


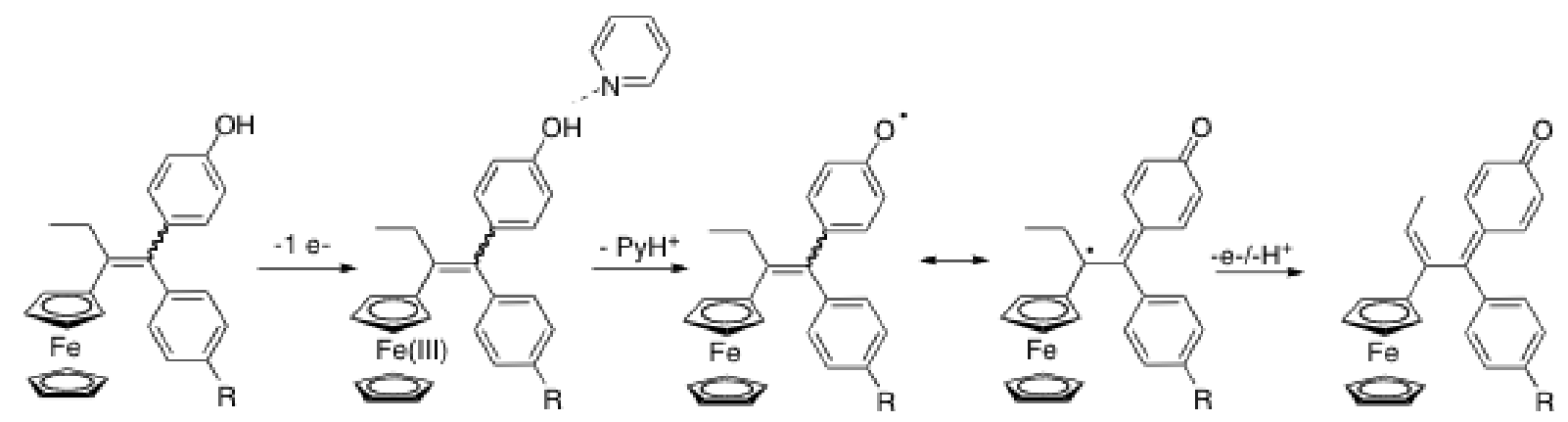

Scheme S1. Mechanism of formation of quinone methides.
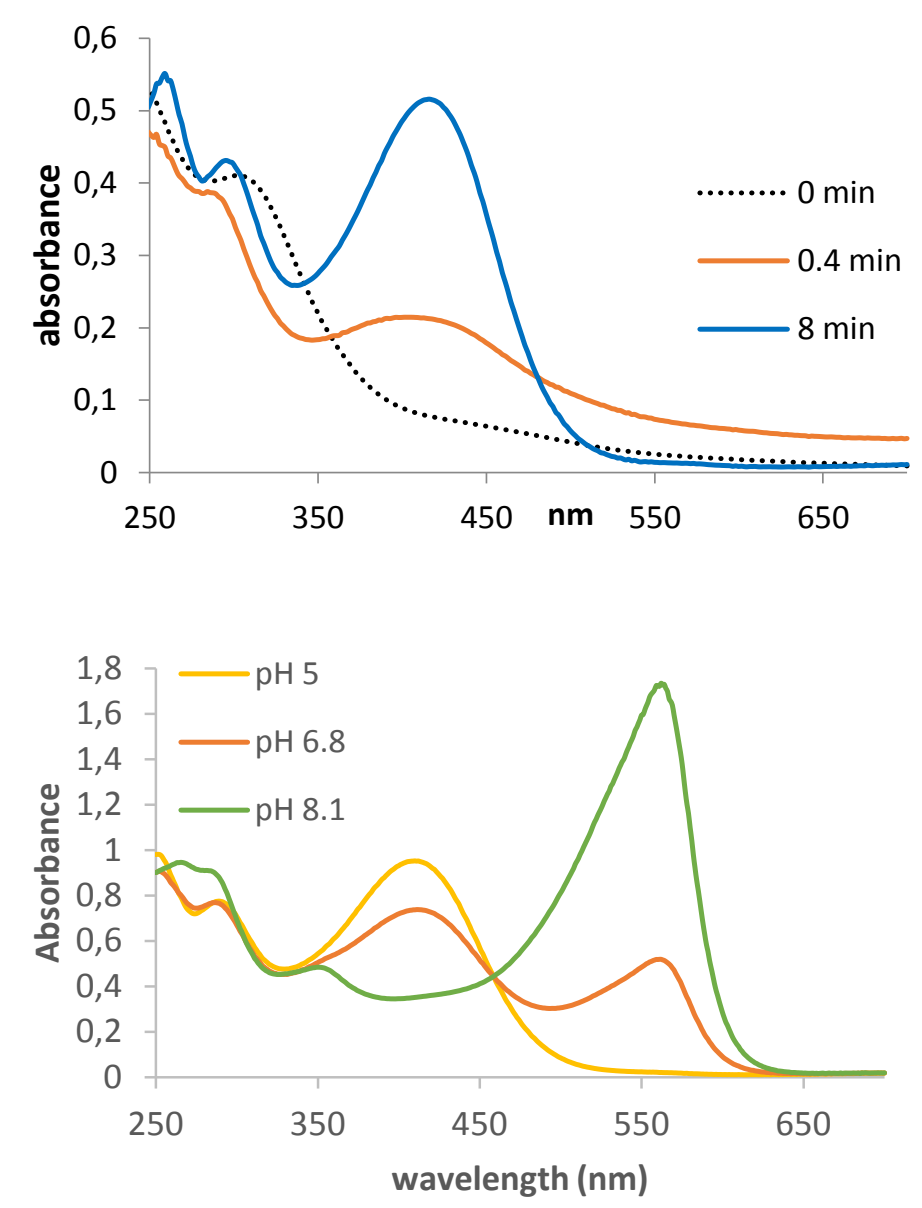

Figure S1. Upper panel: Time evolution of the UV-Vis spectrum of $1(50 \mu \mathrm{M})$ incubated at 25 ${ }^{\circ} \mathrm{C}$ in the presence of HRP $(46 \mathrm{nM})$ and $\mathrm{H}_{2} \mathrm{O}_{2}(200 \mu \mathrm{M})$ in citrate-phosphate buffer pH 5 (48.5 $\mathrm{mM}$ citric acid and $103 \mathrm{mM} \mathrm{Na}_{2} \mathrm{HPO}_{4}$ ) containing 10\% DMSO Pure 1 (0 min): band at 304 $\mathrm{nm}$; after $0.4 \mathrm{~min}$ : bands at $406 \mathrm{~nm}$ (broad), $286 \mathrm{~nm}$ (shoulder); after $8 \mathrm{~min}$ : bands at $416 \mathrm{~nm}$ (intense), 296 and $262 \mathrm{~nm}$. Lower panel: uv-visible spectra of mixtures of 1 (50 $\mu \mathrm{M}), \mathrm{HRP}(46$ $\mathrm{nM})$ and $\mathrm{H}_{2} \mathrm{O}_{2}(200 \mu \mathrm{M})$ in buffer containing 10\% DMSO at various $\mathrm{pH}$. Spectra measured after 2 min incubation at $25^{\circ} \mathrm{C}$. 

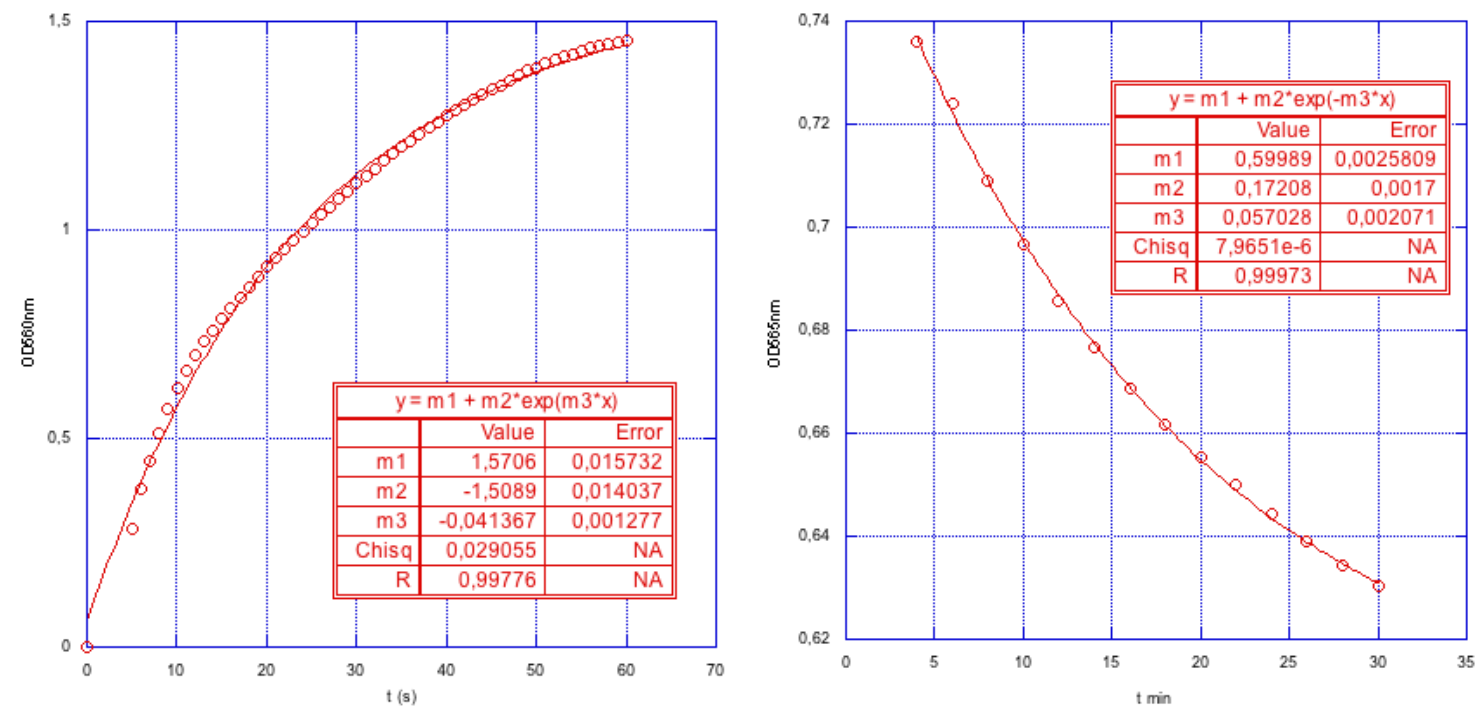

Figure S2. Enzymatic oxidation of $1(50 \mu \mathrm{M})$ by $\mathrm{HRP}(46 \mathrm{nM})$ and $\mathrm{H}_{2} \mathrm{O}_{2}(200 \mu \mathrm{M})$ in Tris- $\mathrm{HCl}$ buffer $\mathrm{pH} 8.1$ containing 10\% DMSO. Kinetic study of the formation (left panel) and degradation (right panel) of $\mathbf{8 A}$ measured at $560 \mathrm{~nm}$.

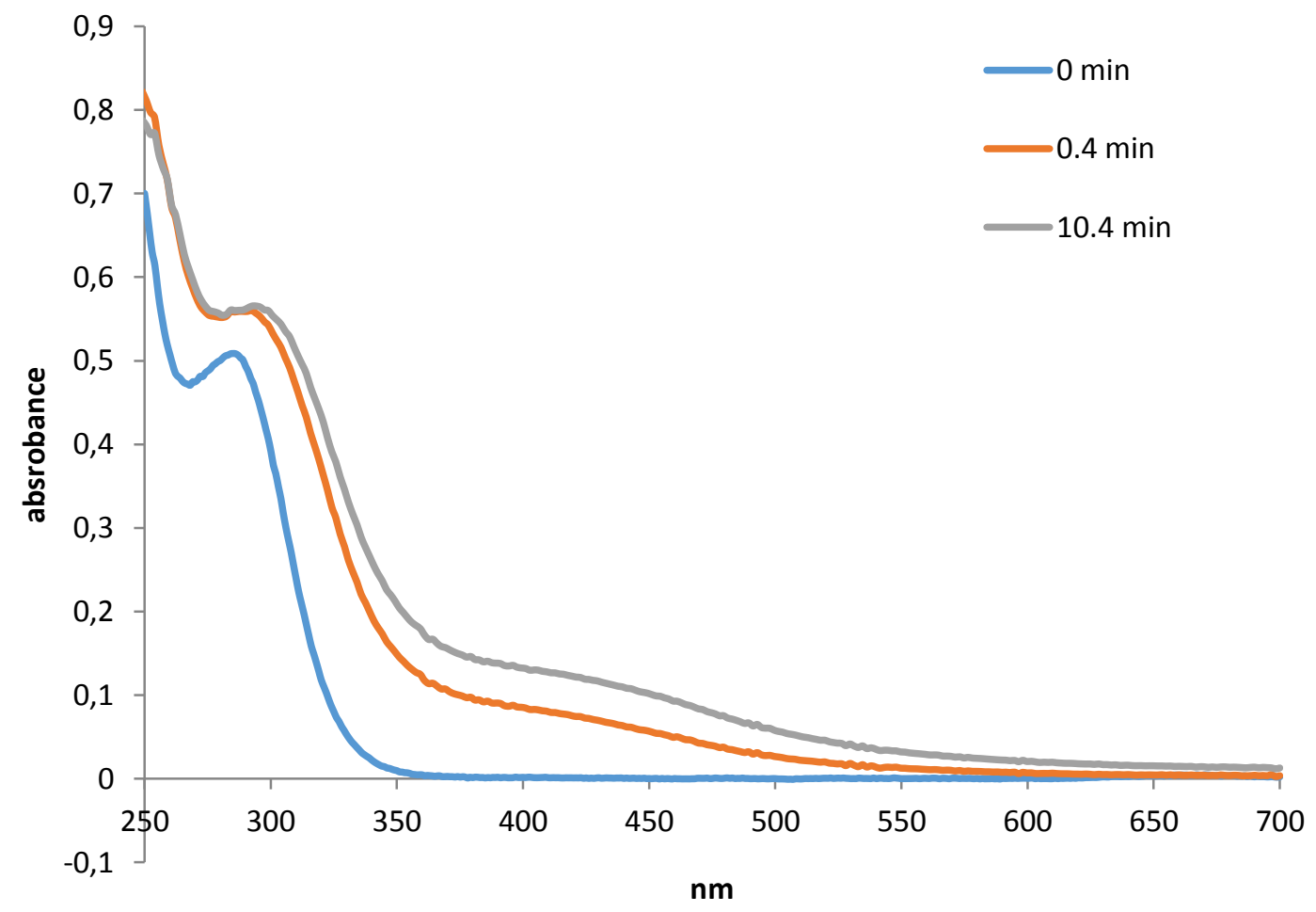

Figure S3. Time evolution of the UV-Vis spectrum of $6(50 \mu \mathrm{M})$ incubated at $25{ }^{\circ} \mathrm{C}$ in the presence of HRP $(46 \mathrm{nM})$ and $\mathrm{H}_{2} \mathrm{O}_{2}(200 \mu \mathrm{M})$ in citrate-phosphate buffer $\mathrm{pH} 5$ (48.5 mM citric acid and $103 \mathrm{mM}$ Na phosphate dibasic) containing 10\% DMSO. Pure 6 (0 min): band at 285 $\mathrm{nm}$; after 0.4 and $10.4 \mathrm{~min}$ : peak at $296 \mathrm{~nm}$. 

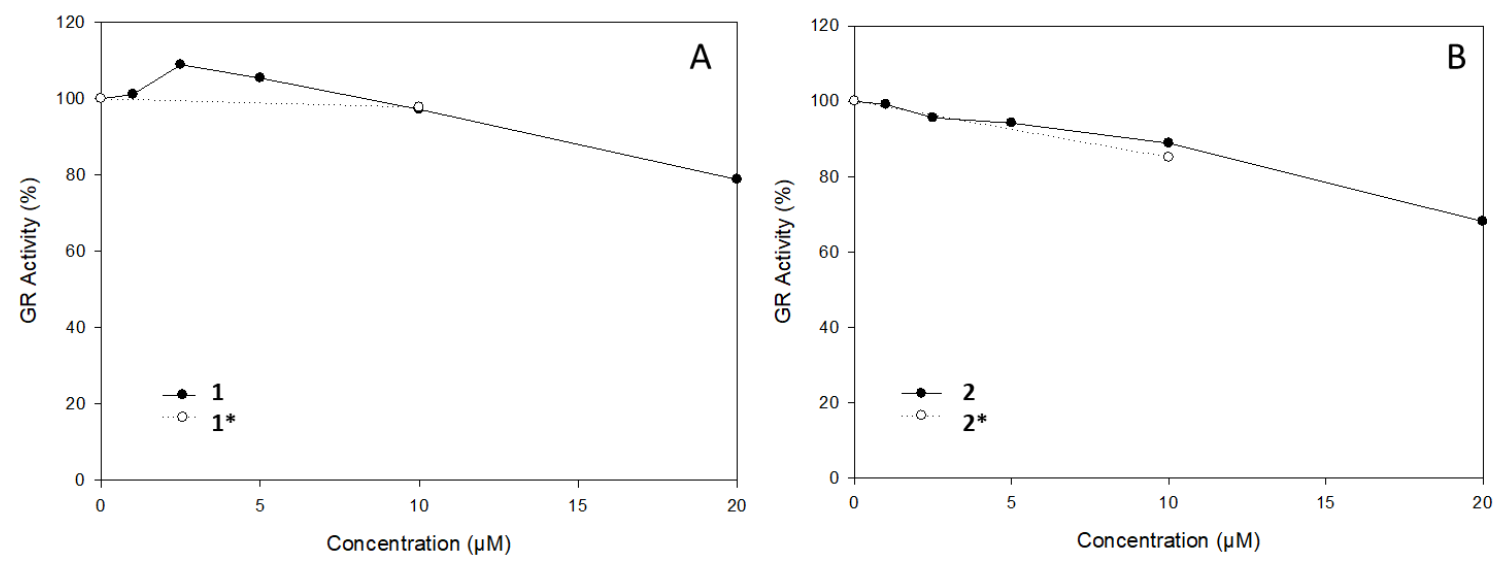

Figure S4. In vitro inhibition of GR by 1 and $\mathbf{1}^{*}(\mathrm{~A}), 2$ and $\mathbf{2}^{*}(\mathrm{~B})$.

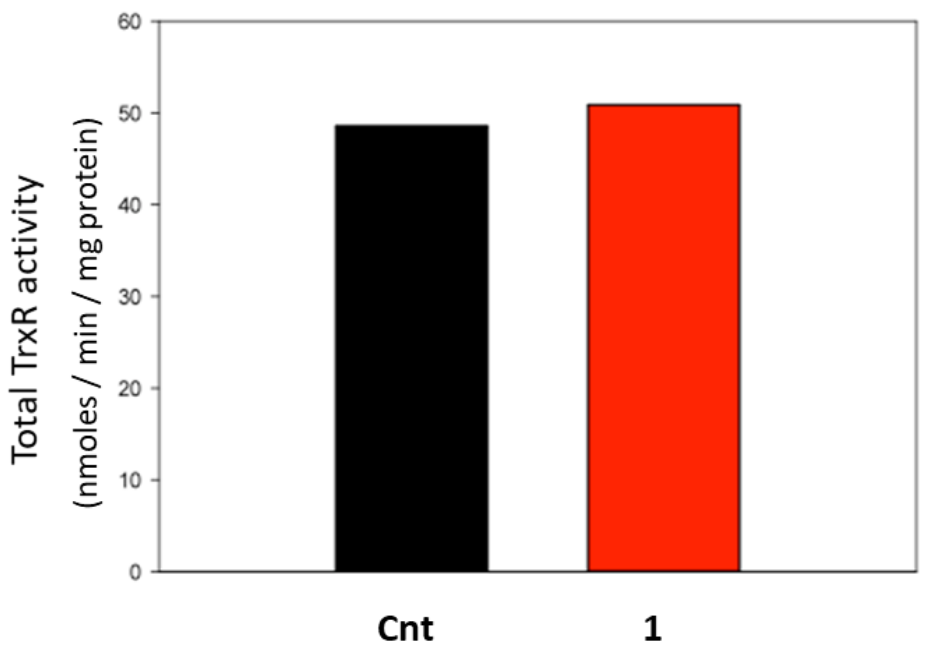

Figure S5. Effect of $\mathbf{1}(15 \mu \mathrm{M})$ on TrxR activity in Jurkat cells after treatment for $18 \mathrm{~h}$. 


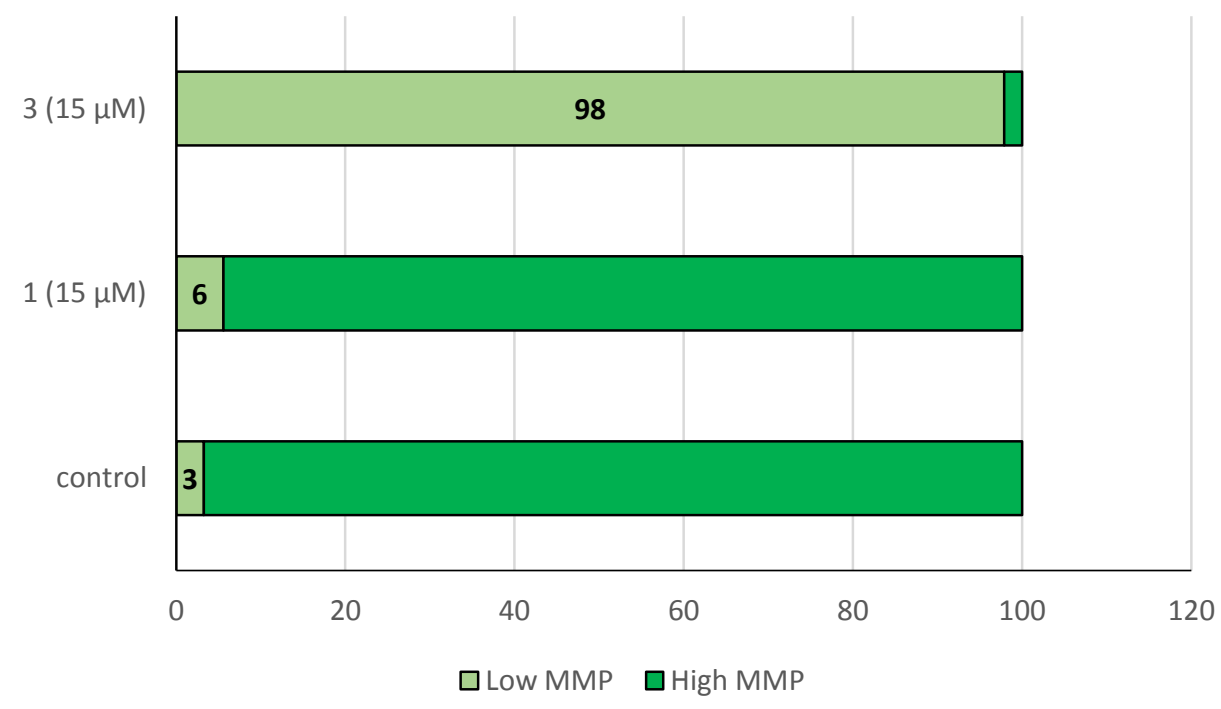

Figure S6. Percentage of Jurkat cells with low and high MMP after incubation with $\mathbf{1}$ or $\mathbf{3}$ (15 $\mu \mathrm{M}, 18 \mathrm{~h})$.

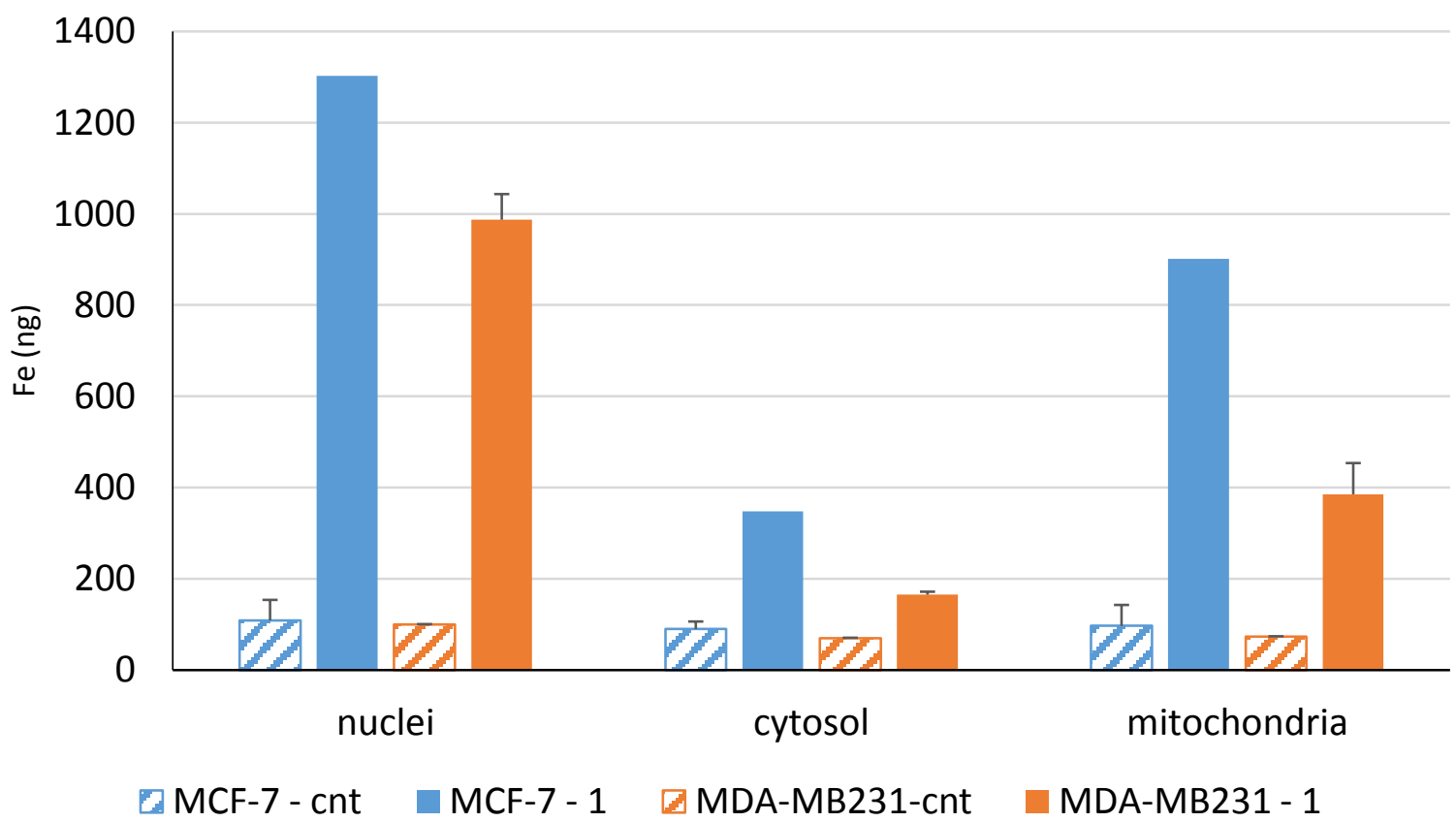

Figure S7. Iron quantity (ng) in subcellular fractions measured by ICP-OES. Cells were incubated with $40 \mu \mathrm{M}$ compound 1 for $18 \mathrm{~h}$ and fractionated as described in the Experimental Section. 


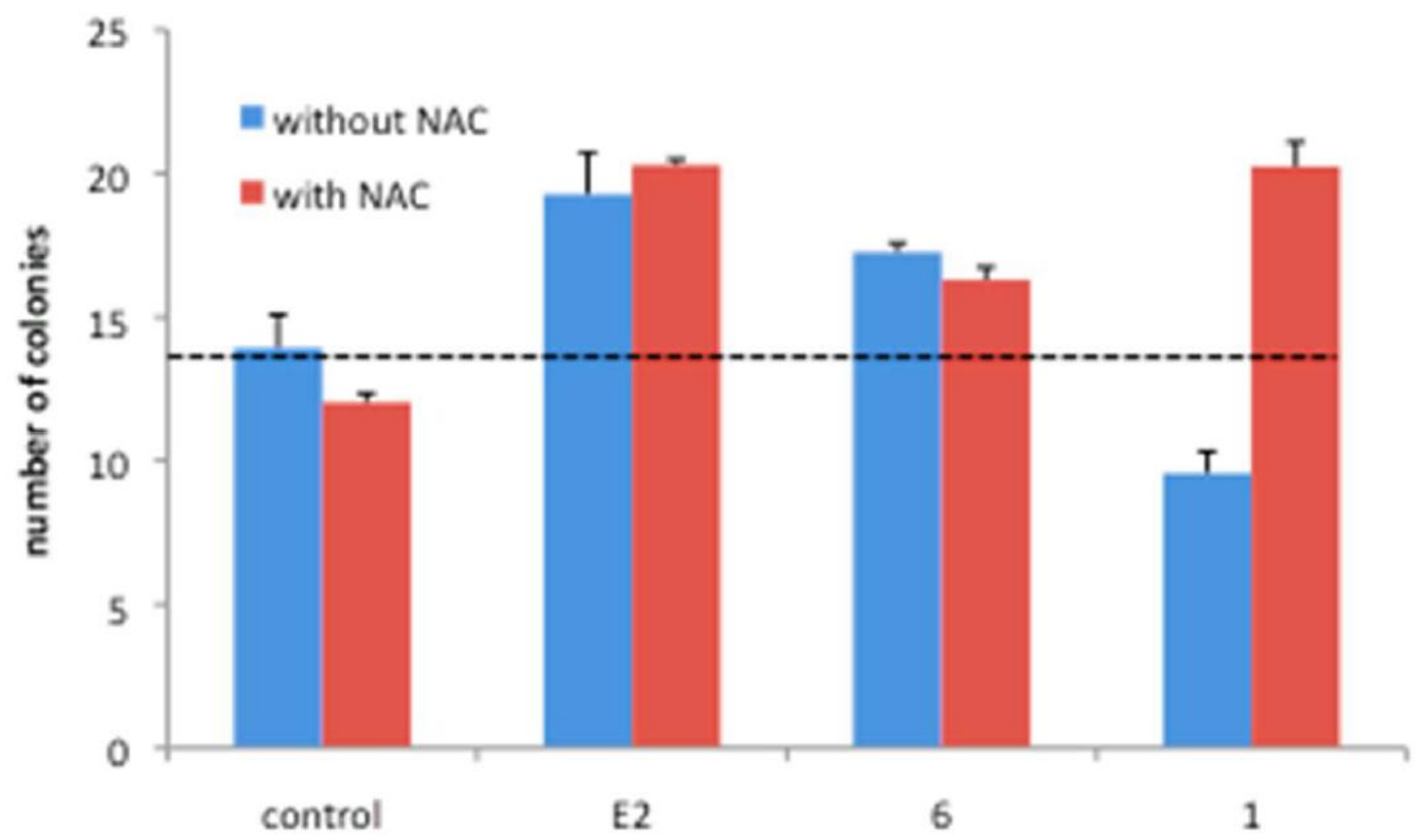

Figure S8. Clonogenic assay in soft agar, on MCF-7 cells (hormone dependent breast cancer cells) incubated with 1 and $6(1 \mu \mathrm{M})$ for 21 days, in the presence or absence of the antioxidant $\mathrm{N}$-acetyl cysteine (NAC, $10 \mathrm{mM}$ ). Mean of 3 experiments. Addition of the antioxidant NAC reversed the cytotoxic effect of 1, demonstrating the role, played by ROS in the expression of its cytotoxicity. It also allows the expression of its estrogenic (proliferative) activity which is almost the same as the one observed with of $1 \mathrm{nM}$ of estradiol (E2). This estrogenic (proliferative effect) is also observed with $\mathbf{6}$ without or with NAC. Experiment was performed as described by: Vessières et al. J. Inorg. Biochem., 2010, 104, 503-510. 